\title{
Cytotoxic effects of pentachlorophenol (PCP) and its metabolite tetrachlorohydroquinone (TCHQ) on liver cells are modulated by antioxidants
}

\author{
Constanze Pietsch • Juliane Hollender • Falk Dorusch • \\ Patricia Burkhardt-Holm
}

Received: 18 March 2014 / Accepted: 25 June 2014 / Published online: 5 July 2014

(C) Springer Science+Business Media Dordrecht 2014

\begin{abstract}
The worldwide distribution and high bioaccumulation potential of pentachlorophenol (PCP) in aquatic organisms imply a high toxicological impact in aquatic systems. Firstly, our investigations show that, similar to mammalian cell lines, PCP can be metabolized to tetrachlorohydroquinone (TCHQ) in the permanent cell line derived from rainbow trout liver cells (RTL-W1). Moreover, we demonstrate that PCP as well as its metabolite TCHQ is capable of influencing the viability of these cells. Three cell viability assays were performed to assess possible cellular targets of these substances. Thus, the cytotoxicity of the PCPderivative TCHQ was shown for the first time in a fish cell line. Further investigations revealed the involvement of ROS in the cytotoxicity of PCP and its
\end{abstract}

\section{Pietsch $(\bowtie)$}

Institute of Natural Resource Sciences (IUNR), Zurich University of Applied Sciences (ZHAW), Gruental, P.O. Box, 8820 Waedenswil, Switzerland

e-mail: constanze.pietsch@zhaw.ch

C. Pietsch · P. Burkhardt-Holm

Man-Society-Environment, Department of Environmental

Sciences, University Basel, Vesalgasse 1, 4051 Basel,

Switzerland

\section{J. Hollender $\cdot$ F. Dorusch}

Eawag, Swiss Federal Institute of Aquatic Science and

Technology, Überlandstrasse 133, 8600 Dübendorf,

Switzerland

P. Burkhardt-Holm

Department of Biological Sciences, University of Alberta, CW 405 Biological Sciences Building, Edmonton, AB T6G 2E9, Canada metabolite TCHQ. The observation of oxidative stress provides a plausible explanation for the increased cytotoxicity at higher concentrations especially for PCP and implies possible mechanisms underlying these observations. In addition, antioxidants such as ascorbic acid and quercetin modulate the detrimental effects of PCP and TCHQ whereby both compounds exacerbate the cytotoxic effects of high PCP and TCHQ concentrations.

Keywords Antioxidants - Ascorbate - Cytotoxicity . Oxidative stress · Pentachlorophenol-PCP. Quercetin . Tetrachlorohydroquinone-TCHQ

$\begin{array}{ll}\text { Abbreviations } \\ \text { EtOH } & \text { Ethanol } \\ \text { FBS } & \text { Fetal bovine serum } \\ \text { MeOH } & \text { Methanol } \\ \text { NR } & \text { Neutral red } \\ \text { PCP } & \text { Pentachlorophenol } \\ \text { PI } & \text { Propidium iodide } \\ \text { RTL-W1 } & \text { Rainbow trout liver cells } \\ \text { ROS } & \text { Reactive oxygen species } \\ \text { SOD } & \text { Superoxide dismutase } \\ \text { TCHQ } & \text { Tetrachlorohydroquinone } \\ \text { MTT } & \text { Thiazolyl blue tetrazolium bromide }\end{array}$

\section{Introduction}

Chlorophenol chemicals are widely distributed in the environment and have even been detected in ambient air 
of rural areas and in mountain regions (WHO 1987; Schummer et al. 2006). The frequently occurring persistent environmental pollutant pentachlorophenol (PCP) has been proposed to be carcinogenic (WHO 2003). However, literature on toxic mechanisms of action of PCP at the cellular level is scarce.

PCP is extensively used as a biocide and wood preservative. Additionally, it has been shown that several environmental chemicals, such as lindane, pentachloronitrobenzene, and pentachlorobenzene, can be metabolized to PCP in animals and plants (Koss and Koransky 1978; van Ommen et al. 1985; Renner and Mücke 1986; WHO 2003). Due to its worldwide distribution, PCP levels in the range of $0.01-0.09 \mu \mathrm{M}$ in groundwater have been reported (WHO 1987) although, for example, extreme levels of $>700 \mu \mathrm{M}$ PCP have been found due to an industrial point source for chlorophenols (Lampi et al. 1990). Similarly, surface waters are usually contaminated with less than $0.04 \mu \mathrm{M}$ PCP but industrial effluents introduced as much as $564 \mu \mathrm{M}$ PCP into the environment in the past (WHO 1987). Contamination of drinking water usually ranges from 0.00004 to $0.0004 \mu \mathrm{M}$ PCP which is lower than the maximum allowable contamination level of $0.004 \mu \mathrm{M}$ PCP that has been established (WHO 1987; US EPA 2013).

Although its use is severely restricted in many countries, the worldwide distribution of PCP makes it an important pesticide from a toxicological perspective. Therefore, studies have concentrated on behavior of PCP in the environment and the resulting consequences that are published in approximately 150 peer-reviewed publications per year (Yi et al. 2008). Its metabolism in humans has been reported to be extensive in contrast to its elimination which is slow (Proudfoot 2003). Additionally, several studies also determined the toxic potential of this substance. For example, the investigation of cytotoxic effects and cell death mechanisms showed an $\mathrm{EC}_{50}$ value at $24 \mathrm{~h}$ for PCP of $0.11 \mathrm{mmol} \mathrm{L}^{-1}$, whereas the $\mathrm{EC}_{50}$ value at $48 \mathrm{~h}$ was calculated to be at $0.06 \mathrm{mmol} \mathrm{L}^{-1}$ in a mammalian fibroblast cell line as determined by the thiazolyl blue tetrazolium bromide (MTT) reduction assay (Chen et al. 2004). However, literature on toxic mechanisms of action of PCP at the cellular level is scarce. Since PCP shows high stability when dissolved in water (Kulikov and Holder 2008) several studies also investigated the effects of PCP on aquatic organisms which can be considered to be quite sensitive to PCP (Johnson and
Finley 1980). Accordingly, invertebrates showed $\mathrm{LC}_{50}$ values between 1.09 and $3.68 \mu \mathrm{M}$ after exposure for $24 \mathrm{~h}$ (Song 2007). Moreover, high bioaccumulation factors for PCP in adipose tissue and bile have been shown for fish (Glickman et al. 1977). Furthermore, concentrations of up to $61 \mathrm{\mu g} \mathrm{kg}^{-1}$ PCP have been measured in cyprinids in a Chinese river system (Ge et al. 2007). After an accidental spill of technical PCP, the surviving fish showed accumulation of this substance ranging from 19 to $221 \mathrm{mg} \mathrm{kg}^{-1}$ in muscle, gills, and liver for several months (Pierce and Victor 1978). In addition, the development of embryos and early life stages of zebrafish and rainbow trout were found to be impaired by PCP exposure (Hodson and Blunt 1981; Zheng and Zhu 2005). Impaired growth and detrimental effects on gonadal development have also been observed in adult fish belonging to different fish species (Hanson et al. 2007). These findings together with the observation that acute toxicity of PCP to fish occurred after $96 \mathrm{~h}$ within a concentration range of 0.19 to $1.28 \mu \mathrm{M}$ depending on the species (Dwyer et al. 2005) lead to the conclusion that fish are very sensitive to PCP although the mechanisms for this remain to be investigated.

Finally, fish cell lines have been found to be sensitive to PCP as well. Accordingly, primary hepatocytes and a permanent cell culture from rainbow trout liver, a good cell model for screening chemical toxicity in vitro, have already been used to show cytotoxic effects of PCP (Schreer et al. 2005). Additionally, it was found that PCP is also toxic to the fibroblast-like $R_{1}$ cell line derived from rainbow trout showing an $\mathrm{EC}_{50}$ of $0.24 \mathrm{mM}$ after incubation for $24 \mathrm{~h}$ (Segner and Lenz 1993). Other investigations led to the assumption that fish cell lines are more sensitive to PCP than mammalian cell cultures (Castaño and Gómez-Lechón 2005).

In the present study, the rainbow trout liver cells (RTL-W1) cells were used to evaluate the mechanisms of cytotoxic effects of PCP and its metabolite tetrachlorohydroquinone (TCHQ) in vitro. The toxic effects of these substances in RTL-W1 cells were confirmed as a function of chemical concentration by using two cell viability assays, the assay determining uptake of neutral red and the MTT assay to establish their doseresponse relationships. In addition, the membrane integrity was also analyzed in cells exposed to these substances by using the fluorescent dye propidium iodide to confirm the severeness of the cellular alterations. Furthermore, we are unaware of any published study 
that has reported oxidative cell damage to permanent fish cell cultures due to exposure to PCP or its derivative TCHQ. Thus, production of reactive oxygen species (ROS) and activity of the superoxide dismutase (SOD) in cells treated with PCP or TCHQ were analyzed to reveal whether oxidative stress may be responsible for the toxicity of these substances. This may help to elucidate the basis for the mechanisms and the cellular targets in fish cells when exposed to the chosen chemicals. The antioxidants ascorbic acid and quercetin have been used in order to evaluate whether these agents are capable of increasing the tolerance of the RTL-W1 cells to the detrimental effects of PCP and TCHQ. These studies are important in order to generate baseline data on cytotoxicity in fish cells and to make a significant comparison of the toxic potency of PCP and its metabolite TCHQ.

\section{Materials and methods}

Chemicals

All chemicals were obtained from Sigma-Aldrich (Buchs, Switzerland) unless indicated otherwise. PCP was purchased at $98 \%$ purity, whereas TCHQ had a purity of more than $99.5 \%$. Stock solutions of PCP and TCHQ were prepared in methanol $(\mathrm{MeOH})$ and maintained in darkness at $4{ }^{\circ} \mathrm{C}$. Ascorbic acid stock solutions were prepared in Earle's medium, whereas quercetin was solubilized in ethanol (EtOH). Solvent concentrations in the exposition media did not exceed $0.1 \%(v / v)$.

Cell culture and exposure

The RTL-W1 cells derived from rainbow trout liver cells were maintained in complete L-15 medium (LuBioScience, Lucerne, Switzerland) supplemented with $5 \%$ fetal bovine serum (FBS), $100 \mathrm{U} / \mathrm{mL}$ penicillin, and $100 \mu \mathrm{g} / \mathrm{mL}$ streptomycin in $75-\mathrm{cm}^{2}$ culture flasks (TPP Techno Plastic Products AG, Trasadingen, Switzerland) at $19{ }^{\circ} \mathrm{C}$ where they were subcultured for 85 times until use. Prior to the experiments, the culture supernatant was discarded and cells were harvested by flushing with $2.5 \mathrm{~mL}$ versene (LuBioScience) twice followed by incubation with trypsin (BioSera, Socochim SA, Lausanne, Switzerland) for $3 \mathrm{~min}$. Afterwards, the trypsinization was terminated by addition of $5 \mathrm{~mL}$ of L- 15 medium containing $5 \%$ FBS. The cells were centrifuged at 1,000 rpm for $5 \mathrm{~min}$ (Megafuge 1.0R, Heraeus), resuspended in complete L-15 medium, and cell numbers were estimated using a Neubauer hemocytometer cell counting chamber. Cells were cultured at initial concentrations of 30,000 cells per well on 96-well microtiter plates (TPP Techno Plastic Products AG) overnight. Thereafter, cells were washed with serum-free Earle's medium $(\mathrm{pH}=7.0)$ since it has been shown that effects on apoptosis depend on the presence of serum (Uhl et al. 1986). Different concentrations of PCP or TCHQ were applied in the same Earle's medium to eight wells, respectively, for $24 \mathrm{~h}$. All experiments were run in three independent replicates. In case of combined exposure to antioxidants and PCP or TCHQ, cells were treated with ascorbic acid or quercetin for $4 \mathrm{~h}$ followed by addition of PCP or TCHQ. In addition, exposures of cells to ascorbic acid and quercetin alone at serial dilutions in Earle's medium were performed for $24 \mathrm{~h}$ to investigate their effects on cell viability and ROS production.

\section{Determination of PCP and TCHQ in media and cells}

For verification of PCP concentrations and the production of TCHQ by RTL-W1 cells, medium samples were taken from freshly prepared solutions before exposure and directly from the cell culture flasks after exposure of cells. Non-adherent cells were removed from medium samples by centrifugation. Volumes of $0.75 \mathrm{~mL}$ of these samples were filled in HPLC vials followed by acidification by addition of $2 \mu \mathrm{L} \mathrm{H}_{3} \mathrm{PO}_{4}$ to each vial. In parallel, adherent cells from cell culture flasks were extracted by washing with $0.5 \mathrm{~mL}$ ethanol directly in the cell culture flasks. All samples and extracts were stored at $4{ }^{\circ} \mathrm{C}$ until further analyses.

For determination of PCP and TCHQ, separation was carried out by HPLC (Agilent 1100) using a Nucleodur C18 end-capped column $(125 \times 2 \mathrm{~mm})$ with a ChromCart precolumn $(5 \times 3 \mathrm{~mm})$ at $30^{\circ} \mathrm{C}$ with a flow rate of $0.5 \mathrm{~mL} \mathrm{~min}^{-1}$. Methanol (eluent $\mathrm{A}$ ) and $5 \mathrm{mM}$ potassium hydrogen phosphate $\left(\mathrm{KH}_{2} \mathrm{PO}_{4}, \mathrm{pH} 2.5\right.$, eluent $\mathrm{B})$ served as mobile phases using the following gradient: $3 \mathrm{~min} 50 \% \mathrm{~A}, 3$ to $5 \mathrm{~min}$ increasing to $90 \%$ A, holding up to $10 \mathrm{~min}$ and then decreasing rapidly to $50 \%$. The total run time was $15 \mathrm{~min}$; the injection volume was set to $100 \mu \mathrm{L}$. Detection was carried out with a fixed wavelength detector at $265 \mathrm{~nm}$. With these settings, PCP elutes at $8.7 \mathrm{~min}$ and TCHQ at $2.2 \mathrm{~min}$. 
Calibration was made using PCP and TCHQ stock solutions of $100 \mathrm{mM}$ each. The stock solutions of these standard compounds were prepared in ethanol and diluted with Earle's medium to a concentration rage of 0.8 to $100 \mu \mathrm{M} \mathrm{PCP}$ and 0.8 to $100 \mu \mathrm{M}$ TCHQ, respectively. The limit of detection (LOD) estimated from the signalto-noise ratio was found to be at $0.78 \mu \mathrm{M}$ whereas a limit of quantitation (LOQ) calculated from the calibration curve was obtained at a concentration of $0.38 \mu \mathrm{M}$ PCP and $0.40 \mu \mathrm{M}$ TCHQ, respectively.

\section{Measurement of cell viability}

To analyze the cytotoxicity of the testing compounds, two commonly used cytotoxicity assays were used. These assays have different mechanistic bases and may thus give some hints to the biochemical mechanism of action of the toxicants. Firstly, cell viability after exposure to the different chemicals was measured by assessing the uptake of neutral red (NR, 3-amino-7dimethylamino-2-methyl-phenanzine hydrochloride) to evaluate membrane integrity and lysosomal function based on the method described by Borenfreund and Puerner (1985) with modifications as described in Pietsch et al. (2011). In parallel, cells were used for MTT assays and propidium iodide (PI) assays to further evaluate mitochondrial activity or membrane integrity as described previously (Pietsch et al. 2011). Each value of different test chemicals and control was based on the mean of eight wells. Data for microtiter plate assays for cell viability are presented as arithmetic mean percentage \pm standard error of means (SEM) of all experiments and replicates in relation to solvent controls.

The concentration values resulting in $50 \%$ reduction of cell survival $\left(\mathrm{EC}_{50}\right)$ were calculated for each compound by regression of the percent response to the substance against the natural logarithm of the compound concentration. The resulting regression equations were used to calculate the concentration of compound that would result in $50 \%$ reduction of cell viability. Since metabolites can be even more toxic than the parent compound, the relative potency (RP) of TCHQ was calculated according the equation:

$\mathrm{RP}_{\mathrm{TCHQ}}=\left(\mathrm{EC}_{50} \mathrm{PCP}\right) /\left(\mathrm{EC}_{50} \mathrm{TCHQ}\right)$

Thus, the $\mathrm{RP}_{\mathrm{THCQ}}$ values were determined for the NR, the MTT, and the PI assay and compared to each other (Table 1). If a metabolite is more toxic than the
Table $1 \mathrm{EC}_{50}$ values calculated as the concentrations of PCP or TCHQ that would result in $50 \%$ reduction of cell viability and the values for the relative potency of TCHQ $\left(\mathrm{RP}_{\mathrm{TCHQ}}\right)$ compared to its parent compound PCP

\begin{tabular}{llll}
\hline & $\begin{array}{l}\mathrm{NR}_{50} \\
\mu \mathrm{M}\end{array}$ & $\begin{array}{l}\mathrm{MTT}_{50} \\
\mu \mathrm{M}\end{array}$ & $\begin{array}{l}\mathrm{PI}_{50} \\
\mu \mathrm{M}\end{array}$ \\
\hline $\mathrm{PCP}$ & 1.55 & 8.91 & 19.95 \\
$\mathrm{TCHQ}$ & 3.09 & 15.85 & 39.81 \\
$\mathrm{RP}_{\mathrm{TCHQ}}$ & 0.50 & 0.56 & 0.50 \\
\hline
\end{tabular}

corresponding parent compound, the RP value would be expected to be higher than 1.0 .

Measurement of ROS production

The production of ROS was analyzed using the fluorescent dye 2',7'-dichlorodihydrofluorescein diacetate $\left(\mathrm{H}_{2} \mathrm{DCF}-\mathrm{DA}\right.$, LuBioScience) in three independent experiments. After treatment of the cells with PCP or TCHQ at different concentrations for $24 \mathrm{~h}$, the exposure media were removed and the cells were washed with phosphate-buffered saline (PBS). Then, $100 \mu \mathrm{L}$ of $\mathrm{H}_{2}$ DCF-DA (at a final concentration of $5 \mu \mathrm{M}$ ) in PBS were added to each well and the plates were incubated for $30 \mathrm{~min}$ at room temperature in the dark. For analyses, the excitation and emission wavelengths of $485 \mathrm{~nm}$ and $530 \mathrm{~nm}$, respectively, were applied using a microplate reader (Infinite M200, Tecan Group Ltd, Männedorf, Switzerland). Since we did not quench the extracellular fluorescence that might be occurring due to leakage of probes, we confirmed the observed effects by assessing the conversion of nitroblue tetrazolium (NBT) salt in parallel. For the NBT test, cells were treated on microtiter plates as described above. After $24 \mathrm{~h}$ of incubation, $100 \mu \mathrm{L}$ of the cell supernatant was replaced by Earle's medium containing $1 \mathrm{mg}$ NBT and cells were further incubated for $3 \mathrm{~h}$. Afterwards, the cell supernatant was discarded and the cells were treated with a methanol-water mixture $(7: 3, v: v)$ for $3 \mathrm{~min}$ which was followed by short drying of the plates. Formazan products were solubilized by addition of $50 \mu \mathrm{L}$ of $2 \mathrm{M}$ potassium hydroxide and $50 \mu \mathrm{L}$ dimethyl sulfoxide (DMSO), and optical densities were measured at $620 \mathrm{~nm}$ using a plate reader (Infinite M200, Tecan Group Ltd). 


\section{Measurement of SOD activity}

For SOD activity determinations, $0.75 \times 10^{6}$ cells were allowed to adhere in $25-\mathrm{cm}^{2}$ tissue culture flasks (TPP Techno Plastic Products AG) overnight. Before exposure to chemicals, cells were washed with Earle's medium and the reagent was added in serum-free Earle's medium for $24 \mathrm{~h}$. For the experiments, a duration of exposure of $24 \mathrm{~h}$ was chosen since we intended to investigate acute toxicity of PCP and its metabolite TCHQ on RTL-W1 cells, and an increased exposure period does not seem to improve the sensitivity of cell culture testings (Castaño and Gómez-Lechón 2005).

After treatment, both attached and unattached cells were harvested. Therefore, supernatants were collected and centrifuged at $300 \times \mathrm{g}$ for $5 \mathrm{~min}$ (Megafuge 1.0R, Heraeus). In addition, adherent cells were trypsinized and the trypsinized cells including floating cells from the medium were combined. All cells were washed with PBS and centrifuged at $1,000 \mathrm{rpm}$ for $5 \mathrm{~min}$ at room temperature. Subsequently, the cell pellet was lysed in ice-cold PBS containing Triton X-100 $(0.1 \%, v / v)$ and $1 \mathrm{mmol} / \mathrm{L}$ phenylmethyl sulfonyl fluoride (PMSF). The resulting lysate was transferred to a glass potter tube and the extract was homogenized manually for $3 \mathrm{~min}$ on ice. Thereafter, the samples were stored at $-80{ }^{\circ} \mathrm{C}$ until determination of SOD activity using the commercial kit from Sigma (Cat.-No. 19160) according to the manufacturer's protocol. In parallel, the protein content was determined after dilution of $50 \mu \mathrm{L}$ of cell extracts with the same volume of PBS, followed by mixing and analyses of the protein concentrations in $25 \mu \mathrm{L}$ aliquots in triplicates using the bicinchoninic acid kit for protein determination (BCA1, Sigma) according to the manufacturer's protocol. Protein concentrations were calculated using a standard curve prepared with bovine serum albumin.

\section{Ascorbate assay}

Exposure of cells to different concentrations of ascorbic acid was performed in 24-well plates (BD Falcon ${ }^{\mathrm{TM}}$ 24well Multiwell Plate, Becton Dickinson AG, Allschwil, Switzerland) using 180,000 cells per well. Treatments were performed in duplicate on four independently treated plates. Concentrations of ascorbic acid were analyzed in medium samples and cell extracts according to the method by Vislisel et al. (2007). Medium samples were mixed with methanol and diethylenetriaminepentaacetic acid (DTPA) to achieve final concentrations of $60 \%(v: v)$ and $250 \mu \mathrm{M}$, respectively. After treatment with ascorbic acid, cells were washed with Earle's medium. Subsequently, the plates were frozen at $-80{ }^{\circ} \mathrm{C}$ to achieve lysis of cells. The thawed cells were then incubated with a methanolwater mixture containing DTPA. All extracts were centrifuged at $12,000 \mathrm{rpm}$ for $10 \mathrm{~min}$ at $4{ }^{\circ} \mathrm{C}$. Subsequently, the supernatant was transferred to new vials which were stored at $-80{ }^{\circ} \mathrm{C}$. Prior to analyses, the samples were centrifuged at $16,000 \mathrm{rpm}$ for $1 \mathrm{~min}$ at $4{ }^{\circ} \mathrm{C}$. Subsamples of $50 \mu \mathrm{L}$ were used for the assay. Ascorbic acid in the samples was first oxidized to dehydroascorbate by addition of $50 \mu \mathrm{L}$ tempol (4-hydroxy-2,2,6,6-tetramethylpiperidinyloxy, $2.3 \mathrm{mM}$ in $2 \mathrm{M}$ sodium acetate buffer) per well, followed by short shaking, and addition of $30 \mu \mathrm{L} o$-phenylenediamine (OPDA, $5.5 \mathrm{mM}$ in $2 \mathrm{M}$ sodium acetate buffer). Fluorescence emission values were recorded at $450 \mathrm{~nm}$ immediately using a plate reader (Infinite M200, Tecan Group Ltd.) with excitation at $345 \mathrm{~nm}$. Standard curves were prepared with ascorbic acid diluted to 14 different concentrations ranging from 0 to $150 \mu \mathrm{mol} \mathrm{L}^{-1}$ using the methanol-water mixture containing DTPA. In parallel, aliquots of the cell homogenates were also used for protein determinations using the bicinchoninic acid (BCA) assay (Sigma) according to the manufacturer's protocol.

\section{Statistics}

Data of ROS determinations and cell vitality analyses are presented as the mean \pm SEM from three independent cell cultures which were measured in eight replicates. Measurements in duplicates were used for analysis of ascorbic acid in medium and cell extracts from eight independent cultures. Effects of treatments were determined by comparison of treatment groups to controls using Friedman test followed by Wilcoxon test (SPSS 9.0 for Windows). A $P$ value of $<0.05$ was accepted as being statistically significant.

\section{Results}

Metabolism and toxicity

In initial experiments, PCP metabolism in RTL-W1 cells was investigated. Accordingly, incubation of cells with PCP leads to an increasing amount of this 
substance that could be found in cell extracts (Fig. 1a). For example, $93 \%$ of the initial PCP concentrations could be found in the cells when these were exposed to $12.5 \mu \mathrm{M}$ PCP. However, the portion of PCP that could be identified within the cells decreased from 61 to $36 \%$ of the initial PCP concentrations in the according media when the cells were exposed to PCP concentrations higher than $12.5 \mu \mathrm{M}$ PCP. In all media from PCPtreated cells, TCHQ was identified as a metabolite although the amounts of TCHQ were very low (Fig. 2, showing the results for incubation of cells with $100 \mu \mathrm{M}$ PCP). As expected, PCP could not be detected in culture supernatants when cells were incubated with TCHQ only (Fig. 2b), although TCHQ concentrations in the media ranging from 2.0 to $76.9 \mu \mathrm{M}$ could be measured. The TCHQ levels within the cell extracts remained below the limit of detection when using the current

Fig. 1 Detection of PCP (a) and TCHQ (b) in media before (initial), after cell incubation for $24 \mathrm{~h}$ with PCP or TCHQ (media) and in cell extracts (cells) after exposure determined by means of HPLC analyses method (Fig. 1b) which suggests that TCHQ is rapidly metabolized in cells or interacts with cell components and is therefore no longer detectable.

Assessment of membrane integrity using the NR assay and the MTT reduction assay revealed cytotoxic effects of PCP and TCHQ. A concentration of $0.78 \mu \mathrm{M}$ PCP and higher than $1.56 \mu \mathrm{M}$ PCP significantly lowered the uptake of NR by cells (Fig. 3a). Although, the MTT assay showed increased dye conversion at concentrations between 0.8 and $6.3 \mu \mathrm{M}$ (Fig. 3b), concentrations of more than $6.3 \mu \mathrm{M}$ resulted in a decrease of cell viability measured as a lowered formazan production. Nevertheless, further data analyses showed that the values of NR and MTT assays correlated significantly with each other (Spearman correlation test, $R^{2}=0.59, P<0.01$ ). Cell death which was also indicated by increased PI fluorescence was observed at all PCP concentrations (Fig. 3c). Relative
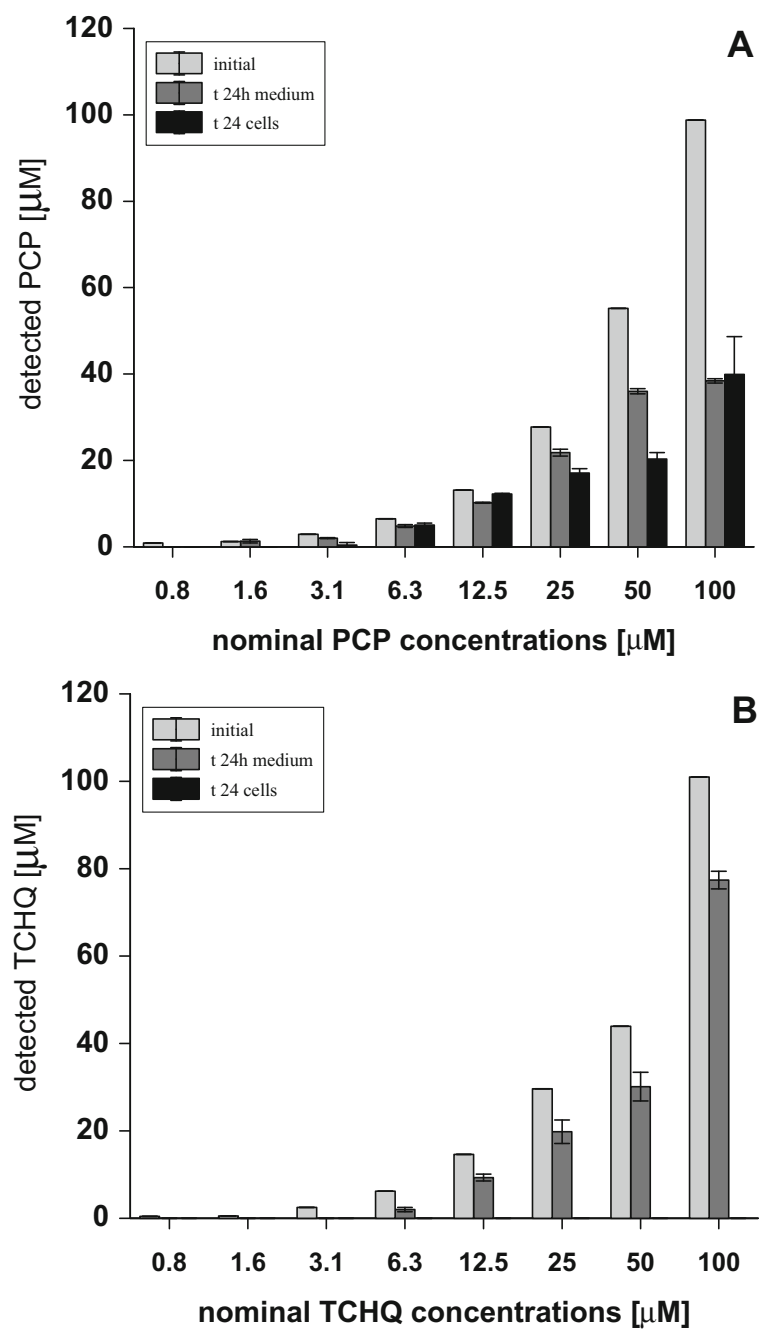
Fig. 2 HPLC chromatogramms of Earle's media containing initial concentrations of $100 \mu \mathrm{M}$ PCP and $100 \mu \mathrm{M}$ TCHQ, respectively, incubated with RTL-W1 cells for $24 \mathrm{~h}$. Retention times are 2.2 and $8.7 \mathrm{~min}$ for TCHQ and PCP, respectively
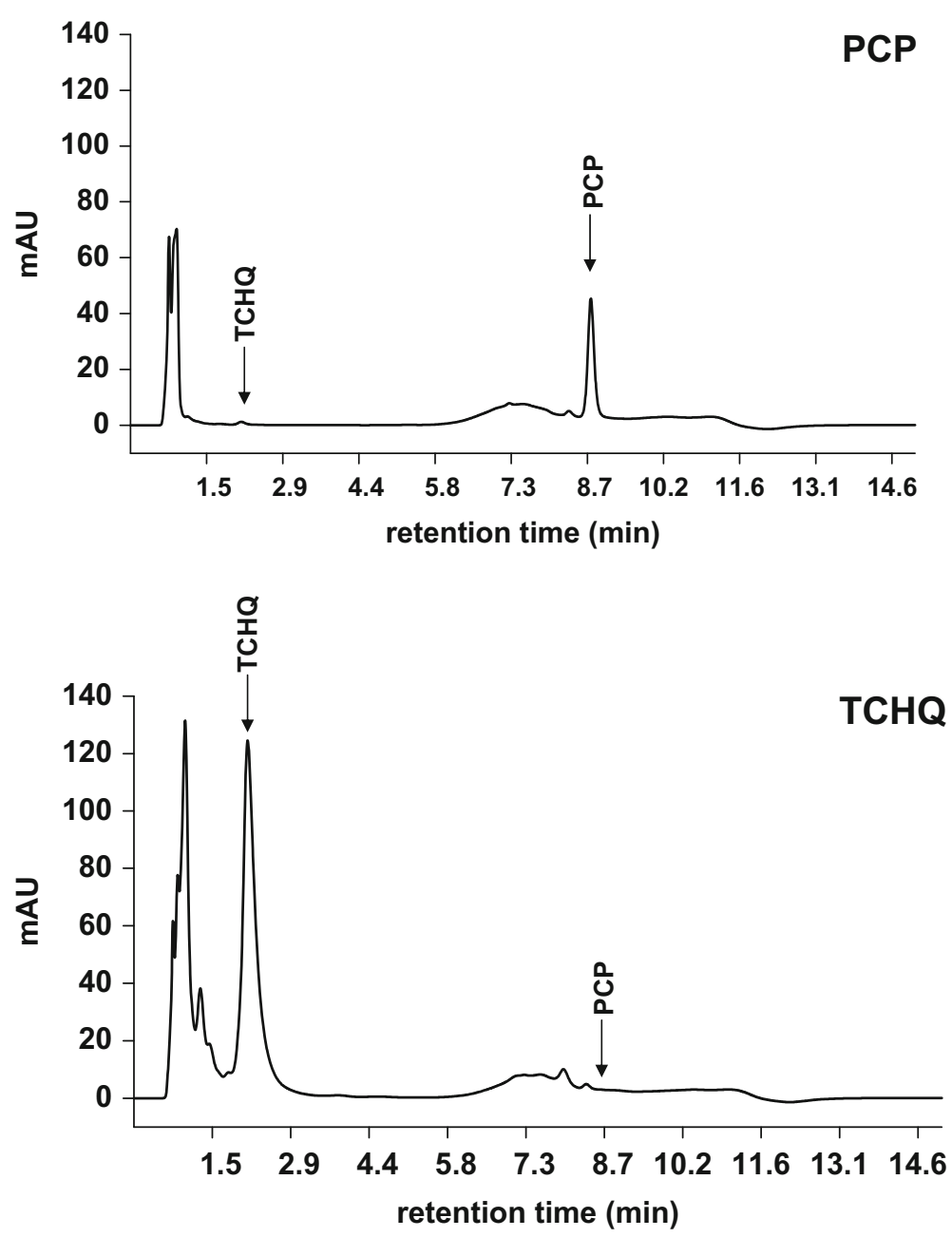

potencies of TCHQ have been calculated for all viability assays showing comparable values independent of the dye that was used for the test (Table 1).

Results from further studies (Fig. 4a) demonstrated that PCP at a concentration of $12.5 \mu \mathrm{M}$ significantly increased ROS production by hepatocytes as assessed by the fluorescent dye $\mathrm{H}_{2}$ DCF-DA. However, the ROS production after treatment with $50 \mu \mathrm{M}$ PCP was found to be significantly reduced $(P<0.05)$. Due to higher variability of the fluorescent emission by cells exposed to $100 \mu \mathrm{M}$ PCP which was probably caused by cellular disturbance and cytotoxic events in these incubations, exposure to this PCP concentration showed only a tendency in reduction of oxidative stress in these cells $(P=0.083)$. In addition, NBT reduction indicated that low concentrations of PCP ( 0.8 and $1.6 \mu \mathrm{M}$, respectively) decreased ROS production $(P<0.05)$ by these cells (Fig. $4 \mathrm{~b})$. The decreased oxidative stress upon exposure to $50 \mu \mathrm{M}$ PCP that has already been observed using the fluorescent dye (Fig. 4a) was confirmed. In contrast, the incubation with $100 \mu \mathrm{M}$ PCP resulted in high NBT conversion (Fig. 4b). Moreover, SOD activity was found to be increased at concentrations higher than $12.5 \mu \mathrm{M}$ PCP (Fig. 4c).

Exposure to TCHQ showed mostly similar results compared to the treatment with PCP. Lysosome activity as assessed by the NR assay was impaired by $6.3 \mu \mathrm{M}$ or higher TCHQ levels (Fig. 3d). Conversion of MTT was increased at $1.6 \mu \mathrm{M}$ and decreased at $6.3 \mu \mathrm{M}$ TCHQ or higher concentrations of this substance (Fig. 3e). Moreover, further data analyses showed that the values of NR and MTT assays correlated significantly with each other (Spearman correlation test, $R^{2}=0.73, P<0.01$ ). PI fluorescence of cells exposed to TCHQ (Fig. 3f) was increased at concentrations of $3.1 \mu \mathrm{M}$ TCHQ or higher reaching very high levels at the high concentrations 

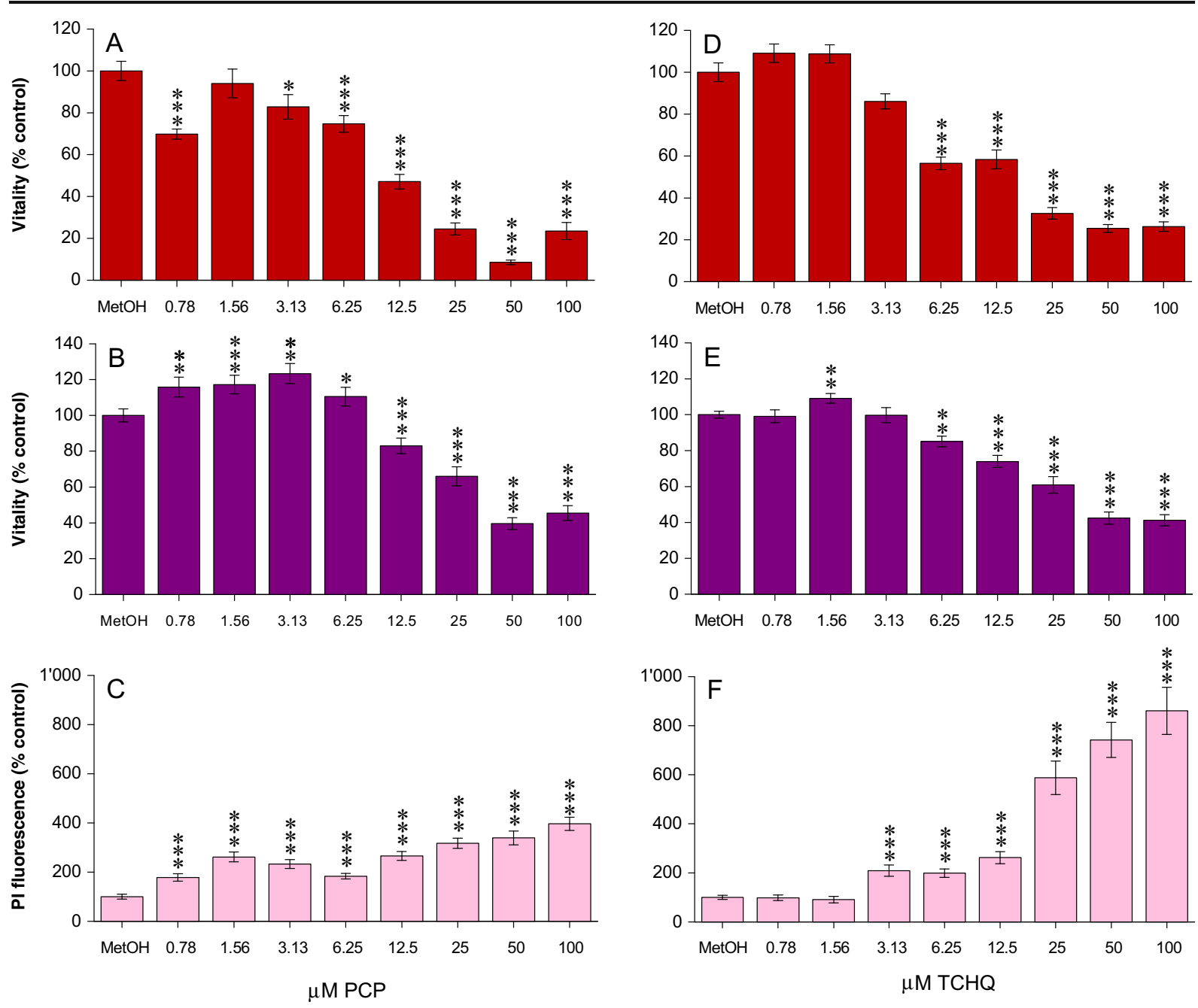

Fig. 3 Cell viability and membrane integrity after incubation of cells with PCP (a-c) and TCHQ (d-f) for $24 \mathrm{~h}$ determined by the uptake of neutral red in RTL-W1 cells $\square$, MTT conversion $\square$, and PI fluorescence by

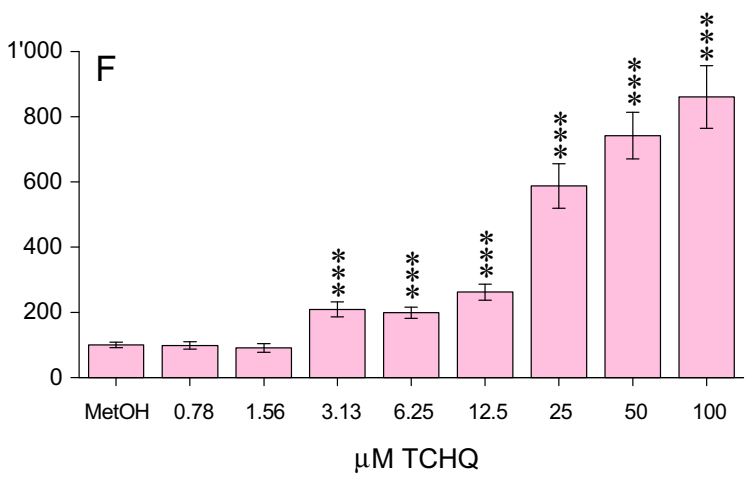

RTL-W1 cells at $90 \mathrm{~min}$ after dye application mean $\pm \mathrm{SEM},{ }^{*} P<0.05, * * P<0.01, * * * P<0.001$

$(P<0.001)$ compared to the maximal PI fluorescence observed in cells incubated with PCP (Fig. 3c).

As can be seen from Fig. 4d, ROS production was high at $1.56 \mu \mathrm{M}$ TCHQ $(P<0.05)$ and decreased at concentrations of $6.3 \mu \mathrm{M}$ or higher $(P<0.01)$. The NBT conversion was also found to be decreased at this range of concentrations of TCHQ (Fig. 4e). However, SOD activity was only elevated in cells exposed to $100 \mu \mathrm{M}$ TCHQ (Fig. 4f).

Effects of ascorbic acid on PCP and TCHQ toxicity

Exposure to ascorbic acid increased ascorbic acid concentrations that could be detected in RTL-W1

cells in a concentration-dependent fashion (Fig. 5). Since ascorbic acid is also a pro-oxidant especially at high concentrations, possible interference with the assays was investigated. Interference with the NR assay was not observed (Fig. 6a). Only the highest ascorbic acid concentration reduced the measurable level of cellular NR accumulation due to influencing cell adherence during the assay. More importantly, continuous exposure of cells to ascorbic acid during the MTT and NBT assay revealed interference of ascorbic acid with the tetrazolium salts by leading to increased dye conversion (Fig. 6b, c). Thus, a washing step for the following experiments was included. 

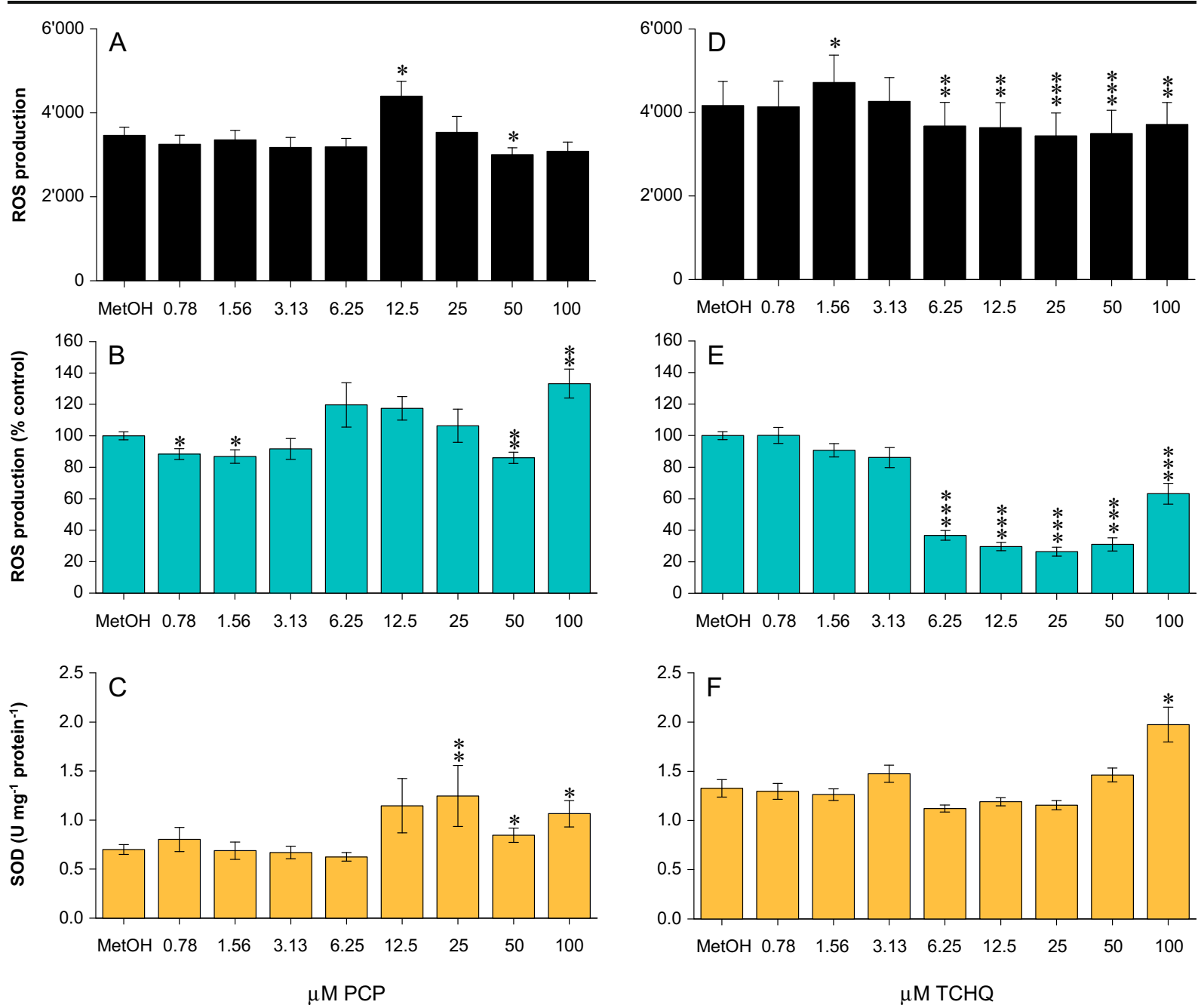

Fig. 4 Oxidative status in RTL-W1 cells measured as ROS production assessed by fluorescence units emitted by H2DCF-DA $\square$ or the NBT assay $\square$ (expressed

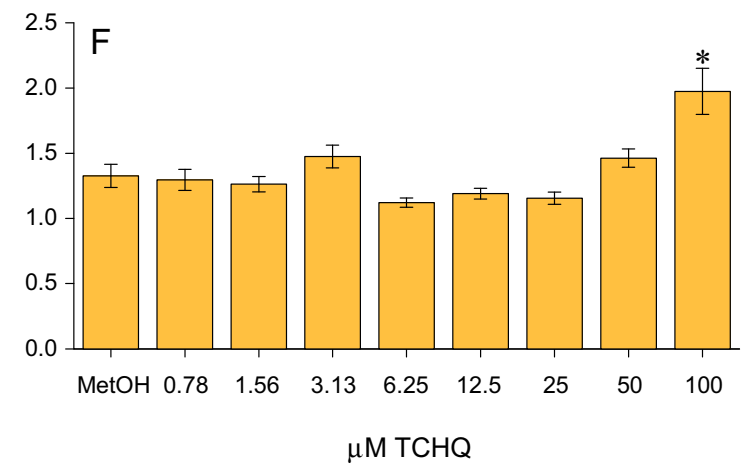

activity $\square$ (expressed as $U$ mg protein ${ }^{-1}$ ) after incubation of RTL-W1 cells with PCP $(\mathbf{a}-\mathbf{c})$ or TCHQ $(\mathbf{d}-\mathbf{f})$ for $24 \mathrm{~h}$, mean $\pm \mathrm{SEM},{ }^{*} P<0.05, * * P<0.01, * * * P<0.001$ relative to control measurements), compared to the SOD

Fig. 5 Uptake of ascorbic acid by RTL-W1 cells measured as fluorescence units $\square$ after exposure to different concentrations of ascorbate in Earle's medium (displayed as nominal concentrations on the $x$-axis) for $24 \mathrm{~h}$, mean \pm $\mathrm{SEM},{ }^{*} P<0.05, * * P<0.01$

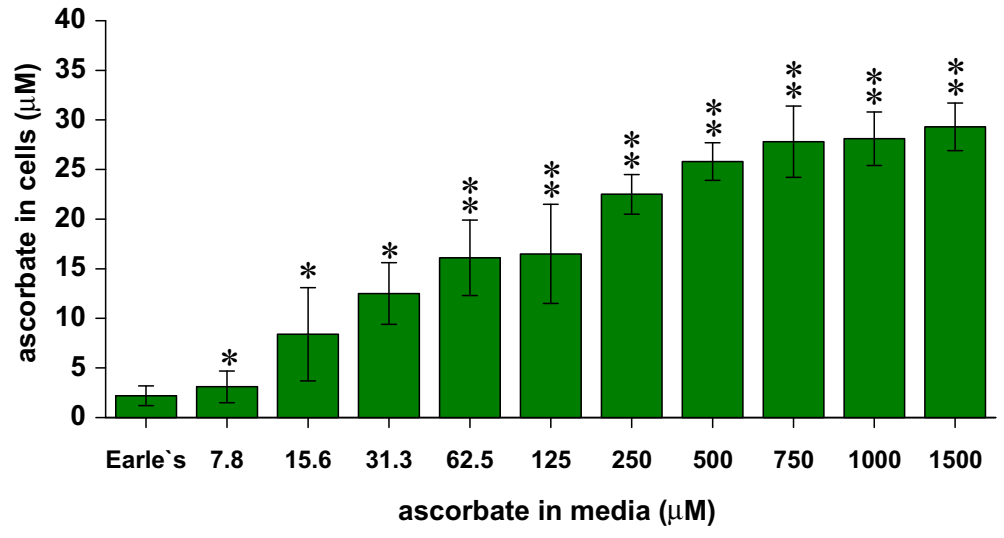


Fig. 6 Influence on the cell viability assays (a: NR $\square$ and b: MTT $\square$ test) and c: ROS production $\square$ due to incubation with different ascorbate concentrations, hatched columns display assay procedures including a washing step before addition of assay due compared to procedures without intermediate washing (filled columns), mean \pm $\mathrm{SEM}, * P<0.05, * * P<0.01$, $* * * P<0.001$
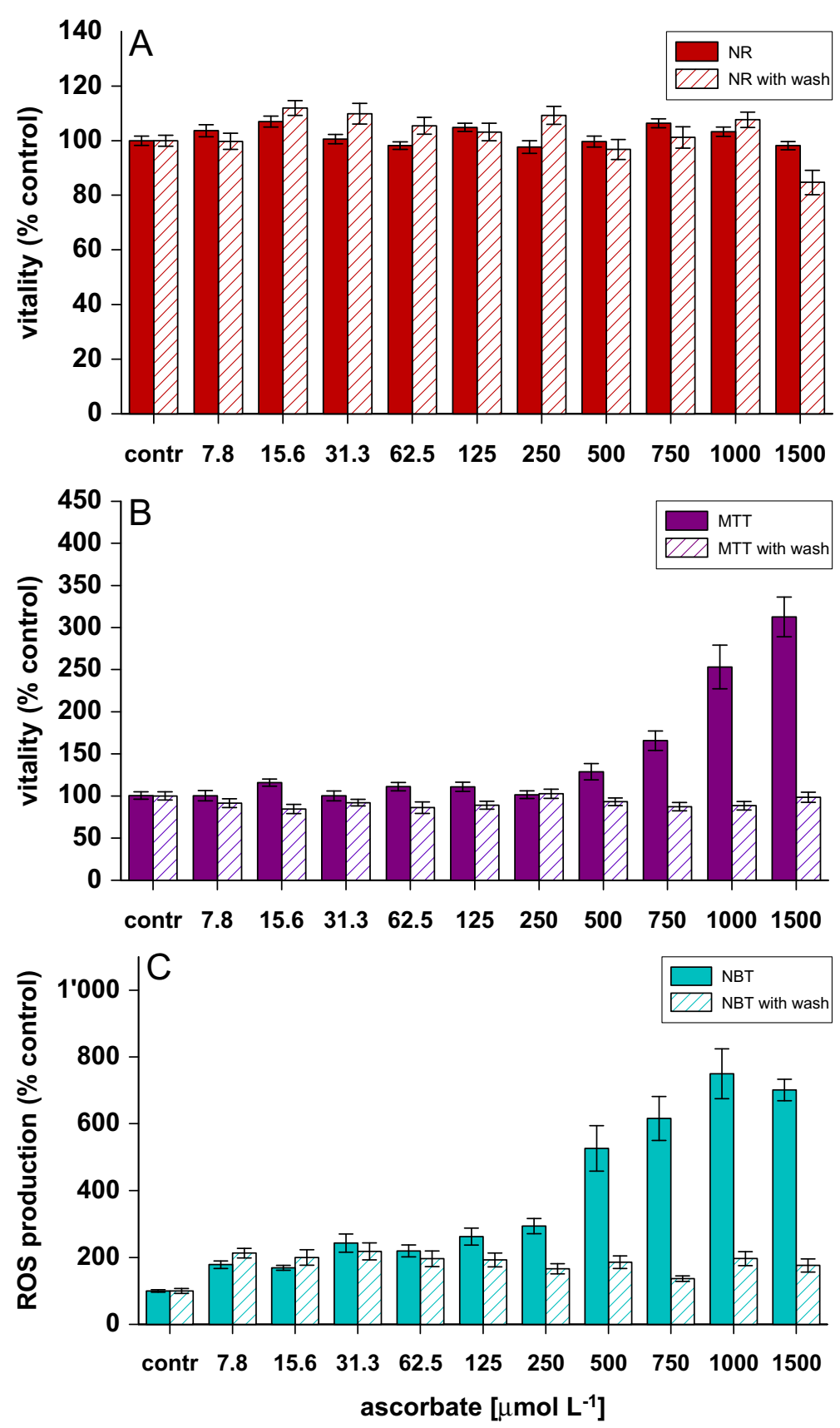

Addition of ascorbic acid before incubation with $12.5 \mu \mathrm{M}$ PCP significantly increased NR retention in cells (Fig. 7a) and did not change MTT conversion by cells (Fig. 7b). In contrast, exposure to $50 \mu \mathrm{M}$ PCP after ascorbic acid addition leads to strongly reduced NR levels in cells (Fig 7d) and increased MTT signals (Fig. 7e). The NBT conversion was increased by coexposure of $250 \mu \mathrm{M}$ ascorbic acid and $12.5 \mu \mathrm{M}$ PCP
(Fig. 7c), whereas all ascorbic acid concentrations increased ROS production when $50 \mu \mathrm{M}$ PCP were added to the cells (Fig. 7e). Preconditioning of RTL-W1 cells with ascorbic acid followed by exposure to $12.5 \mu \mathrm{M}$ TCHQ led to increased NR values at ascorbic acid concentrations of $1,000 \mu \mathrm{M}$ and below that (Fig. 8a). In contrast, co-exposure of ascorbic acid and $50 \mu \mathrm{M}$ TCHQ led to reduced NR retention of cells at all 

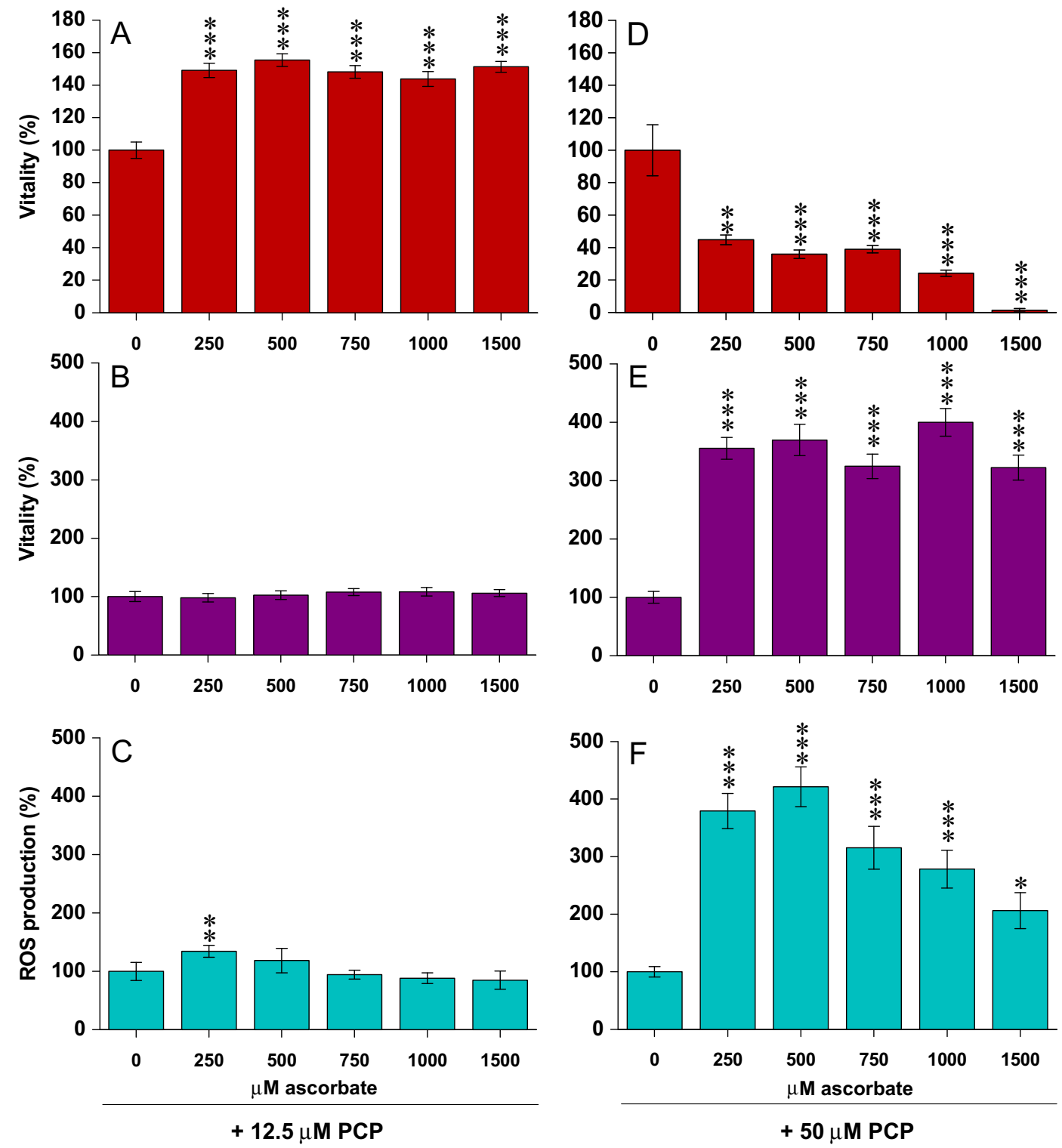

Fig. 7 Cell viability and ROS production after incubation of cells with different concentrations of ascorbate for $24 \mathrm{~h}$ measured as the uptake of neutral red in RTL-W1 cells $\square$, MTT conversion $\square$, and ROS measurement by NBT conversion $\square$ with

simultaneous application of $12.5 \mu \mathrm{M}$ TCHQ (a-c) or $50 \mu \mathrm{M}$ TCHQ (d-f) $3 \mathrm{~h}$ after ascorbate addition and inclusion of a washing step with Earle's medium before dye application, mean \pm SEM $,{ }^{*} P<0.05, * * P<0.01, * * * P<0.001$

ascorbic acid concentrations (Fig. 8d). Reduced MTT conversion was observed at co-exposure of ascorbic acid concentrations higher than $750 \mu \mathrm{M}$ and TCHQ. Concentrations of more than $250 \mu \mathrm{M}$ ascorbic acid led to reduced ROS production when cells were simultaneously exposed to $12.5 \mu \mathrm{M}$ TCHQ, whereas $50 \mu \mathrm{M}$ TCHQ increased NBT conversion due to co-exposure to 500 and $750 \mu \mathrm{M}$ ascorbic acid and reduced ROS production at the highest concentration of ascorbic acid (Fig. 8e).

Exposure to $12.5 \mu \mathrm{M}$ PCP did not lead to different ascorbic acid concentrations in the media after $24 \mathrm{~h}$ of exposure compared to the exposure to $50 \mu \mathrm{M}$ PCP (Fig. 9a). Similar results were observed for exposures to the two different TCHQ concentrations (Fig. 9b). 

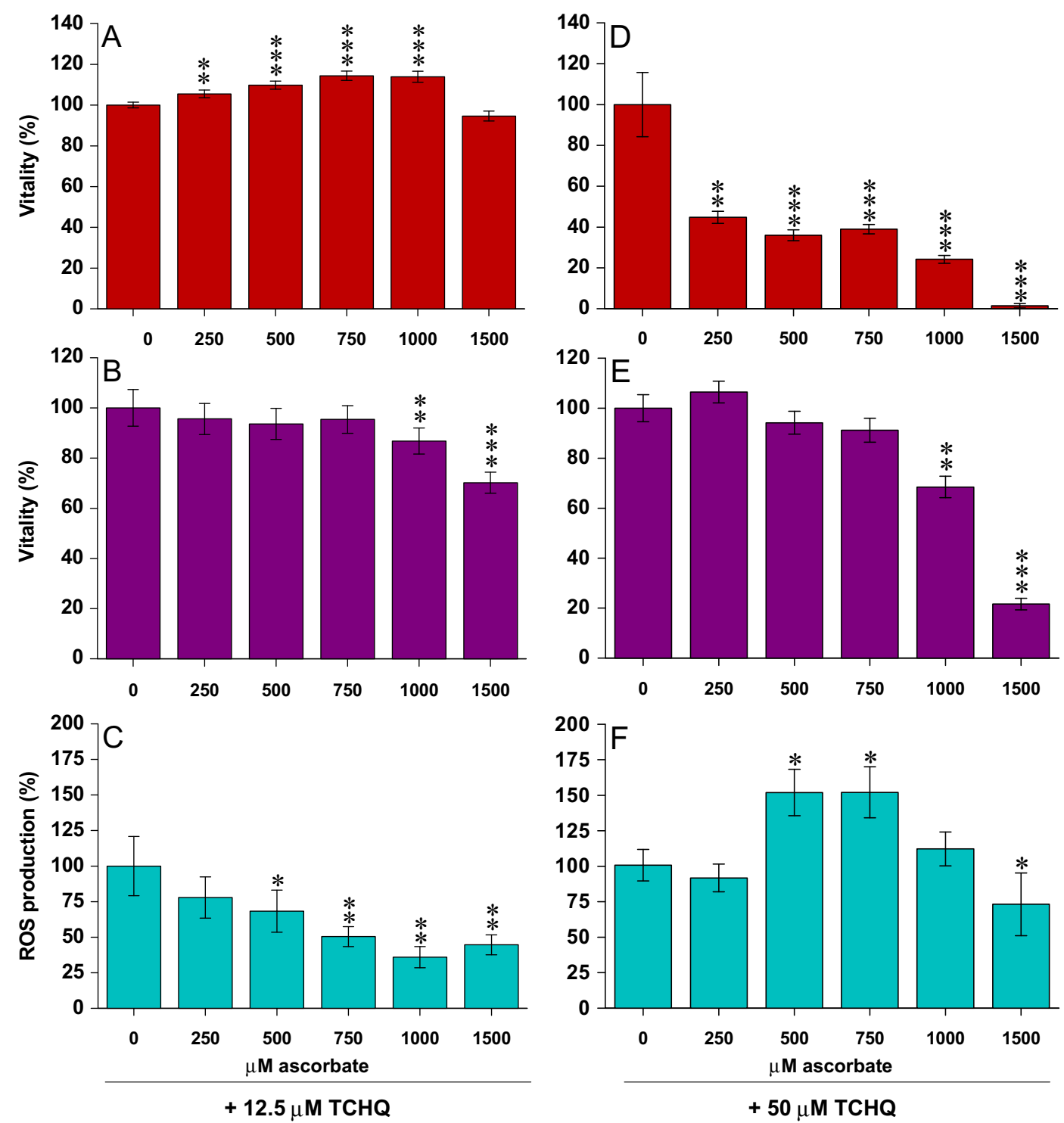

Fig. 8 Cell viability and ROS production after incubation of cells with different ascorbate concentrations for $24 \mathrm{~h}$ measured as the uptake of neutral red in RTL-W1 cells $\square$, MTT conversion , and ROS measurement by NBT conversion $\square$ with the

Effects of quercetin on PCP and TCHQ toxicity

Quercetin at concentrations of less than $2.5 \mu \mathrm{M}$ did not influence NR and MTT assays (Fig. 10). Therefore, concentrations of $1 \mu \mathrm{M}$ quercetin or less were chosen for co-exposure with PCP or TCHQ. These concentrations did not negatively influence cell viability although ROS production was reduced due to exposure to quercetin concentrations of $0.031 \mu \mathrm{M}$ or higher.

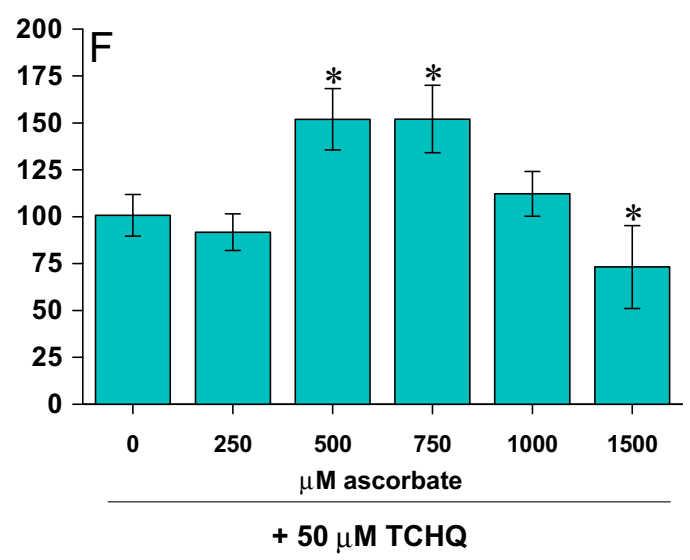

simultaneous application of $12.5 \mu \mathrm{M}$ PCP (a-c) or $50 \mu \mathrm{M}$ PCP (d-f) $3 \mathrm{~h}$ after ascorbate addition and inclusion of a washing step with Earle's medium before dye application, mean \pm SEM, $* P<0.05, * * P<0.01, * * * P<0.001$

The cytotoxic effects of $50 \mu \mathrm{M}$ PCP were even more pronounced after preexposure to quercetin which was not observed when $12.5 \mu \mathrm{M}$ PCP were used (Fig. 11). In addition, both, 12.5 and $50 \mu \mathrm{M}$ PCP, led to increased ROS production after combined exposure with quercetin. The combination of TCHQ and quercetin led to different results showing no cytotoxicity in the NR and MTT assay and reduction of ROS production in some cases (the highest and the lowest quercetin concentration in combination with $50 \mu \mathrm{M}$ TCHQ) (Fig. 12). 


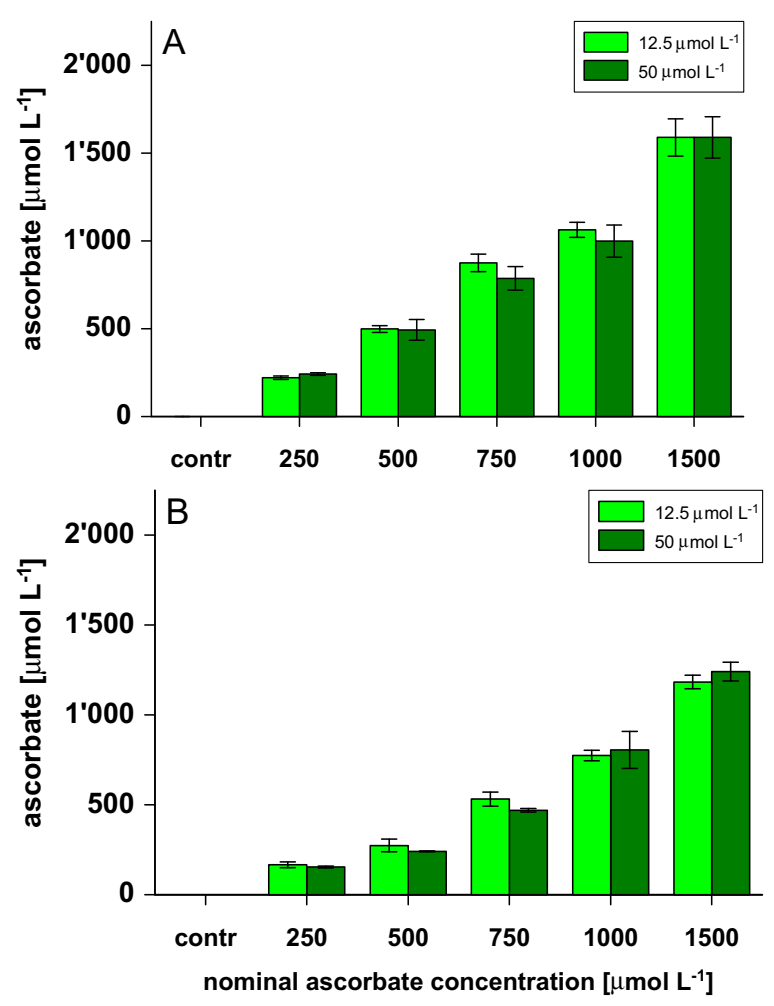

Fig. 9 Ascorbate concentrations in media after simultaneous exposure of RTL-W1 cells to $12.5 \square$ or $50 \square \square \mathrm{mol} \mathrm{L}^{-1}$ PCP (a) or TCHQ (b) measured as fluorescence units (displayed as nominal concentrations on the $x$-axis) for $24 \mathrm{~h}$, mean \pm $\mathrm{SEM},{ }^{*} P<0.05, * * P<0.01$

Surprisingly, the values of the NR assays of cells after treatment with all quercetin concentrations in combination with $50 \mu \mathrm{M}$ TCHQ were found to be strongly increased (Fig. 12d).

\section{Discussion}

\section{Metabolization of PCP}

Our study demonstrated for the first time that RTL-W1 cells are capable of transforming PCP to TCHQ. In other animals, PCP is commonly metabolized to TCHQ and tetrachlorocatechol which can be further oxidized to tetrachloro-1,4-benzoquinone and tetrachloro-1,2-benzoquinone via the corresponding semiquinones (van Ommen and van Bladeren 1989; Lin et al. 1999). In our study, only TCHQ was analyzed because other derivatives are often short-lived and difficult to detect. Oxidation of TCHQ and/or the reduction of tetrachloro1,4-benzoquinone to semiquinones have been reported to be associated with a redox cycling that generates oxygen radicals. The resulting radicals have often been reported to increase DNA lesions in PCP-treated or TCHQ-treated mice (Sai-Kato et al. 1995; Umemura et al. 1999). Oxidative DNA lesions may also be sufficient to induce hepatic carcinogenesis in fish which should be the objective of future research.

Since the liver is considered to be a major site for metabolism of PCP, effects of this substance on hepatocytes have often been investigated, but different assays investigating various endpoints have rarely been applied in one study. Therefore, the degree of inhibition of cell functions in the present experiments was determined by using different endpoints that are useful for identification of specific patterns of cytotoxicity of a certain chemical. The biphasic response of RTL-W1 cells to PCP observed in our study using the MTT assay confirmed previous observations in AML mouse hepatocytes (Dorsey et al. 2004). At higher concentrations, PCP is able to uncouple oxidative phosphorylation and causes damage to mitochondrial membranes (Weinbach 1954; Deichman and Keplinger 1981) and morphological changes in mitochondria have been reported (Smith and Ord 1979). Other cytotoxicity assays revealed that compared to other chlorophenols, PCP showed very high inhibition of NR uptake in goldfish-scale cells (Saito et al. 1991). High sensitivity of the NR assay to PCP in RTL-W1 cells was also observed in the present study. Moreover, hepatocytes of channel catfish showed dose-dependent cytotoxicity of PCP after $48 \mathrm{~h}$ of incubation, although these hepatocytes were less sensitive to PCP than the permanent cell culture from rainbow trout used in our study (Dorsey and Tchounwou 2004). The observed cytotoxicity in the present study is probably due to interference of this substance with structures and/ or processes that are essential for cell survival and proliferation. Our findings, thus, confirm previous studies reporting that high PCP concentrations were responsible for cytotoxic effects of this chemical in mammalian cell cultures. Moreover, our results show a good quantitative correlation of the NR and the MTT assay which has been observed in mammalian cells treated with PCP as well (Caminada et al. 2006).

The observed cytotoxic effects of PCP were also used to calculate $\mathrm{EC}_{50}$ values for this substance. Interestingly, the obtained values were quite different from those that already have been reported. For example, primary hepatocytes obtained from rainbow trout showed $\mathrm{EC}_{50}$ values of $16 \mu \mathrm{M}$, whereas RTL-W1 cells revealed 
Fig. 10 Effects of different quercetin concentrations on $\mathbf{a}: \mathrm{NR}$ $\square$, b: MTT $\square$, and c: NBT $\square$ assays, mean \pm $\mathrm{SEM},{ }^{*} P<0.05, * * P<0.01$
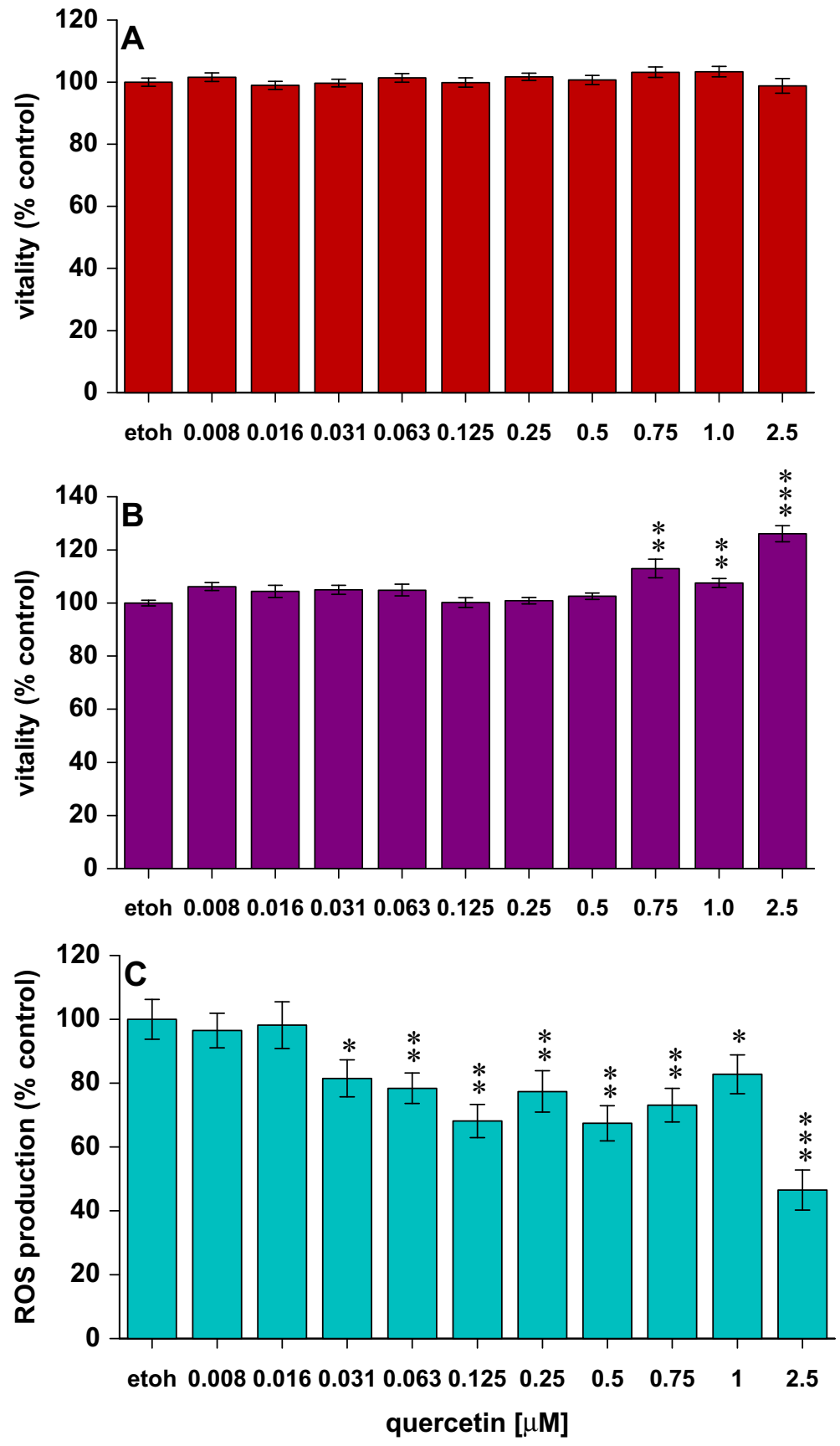

$\mathrm{EC}_{50}$ values at concentrations between 19 and $22 \mu \mathrm{M}$, depending on the fluorescent dye that was chosen for cell vitality analyses (Schreer et al. 2005). The $\mathrm{NR}_{50}$ values for other rainbow trout cell lines treated with PCP for 24 and $48 \mathrm{~h}$ ranged from 36 to $90 \mu \mathrm{M}$ (Castaño et al. 1995; Clemedson et al. 1998; Repetto et al. 2001). Even lower sensitivity has been reported for other fish cell lines (Babich and Borenfreund 1987; Fent and Hunn 1996). This shows that the exposure system used in the present study was very sensitive to PCP. However, it should be noted that toxicity of PCP is $\mathrm{pH}$ dependent (Spehar et al. 1985). Moreover, the presence of FBS, which often has been used for cell exposure in previous studies (e.g. at concentrations of 5 to $10 \%$ by Fent and 

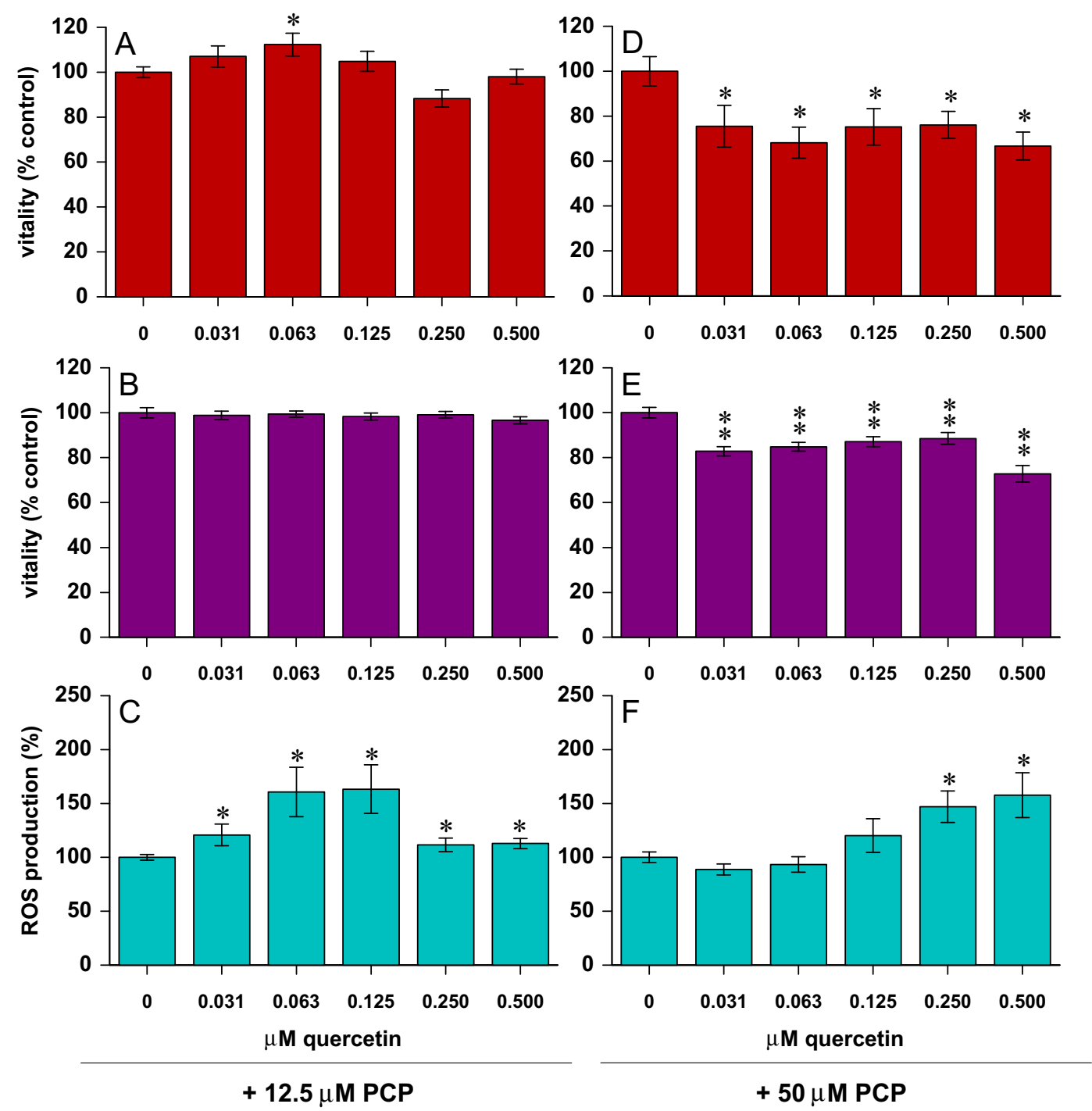

Fig. 11 Effects of preexposure to quercetin on the modulation of NR and $50 \mu \mathrm{M}, \mathbf{d}-\mathbf{f})$, mean $\pm \mathrm{SEM},{ }^{*} P<0.05,{ }^{*} * P<0.01$

Hunn 1996; Schreer et al. 2005, and Dorsey et al. 2004), is also known to influence the availability of PCP and therefore sensitivity of cells may have been underestimated (Uhl et al. 1986). Fortunately, the presence of FBS is not mandatory for fish cell propagation and can be omitted in short-term exposures without negatively affecting cell viability which is advantageous for the evaluation of cytotoxicity of chemicals (Mothersill et al. 1995; Michel et al. 2014). Still, the experimental design may at least partly explain the observed differences in sensitivity of fish cells to PCP. Cell-specific differences in sensitivity are probably also due to either specific mechanisms of action of PCP or its biotransformation into TCHQ. A lower $\mathrm{EC}_{50}$ value for mammalian liver cells exposed to TCHQ compared to the exposure to PCP has already been noted in HepG2 cells, which was assumed to be due to different mechanisms of toxicity for these two compounds (Schroeder et al. 2012). Together with the study of Fent and Hunn (1996), the lower $\mathrm{EC}_{50}$ values of the NR assays compared to the MTT assays in our study suggest a primary role of a lysosomal pathway as a mode of action of PCP and TCHQ in fish cells. Similarly, lysosomes have been described as primary targets of PCP in mammalian Vero cells (Fernández Freire et al. 2005) which supports this hypothesis. The present study shows for the first time 

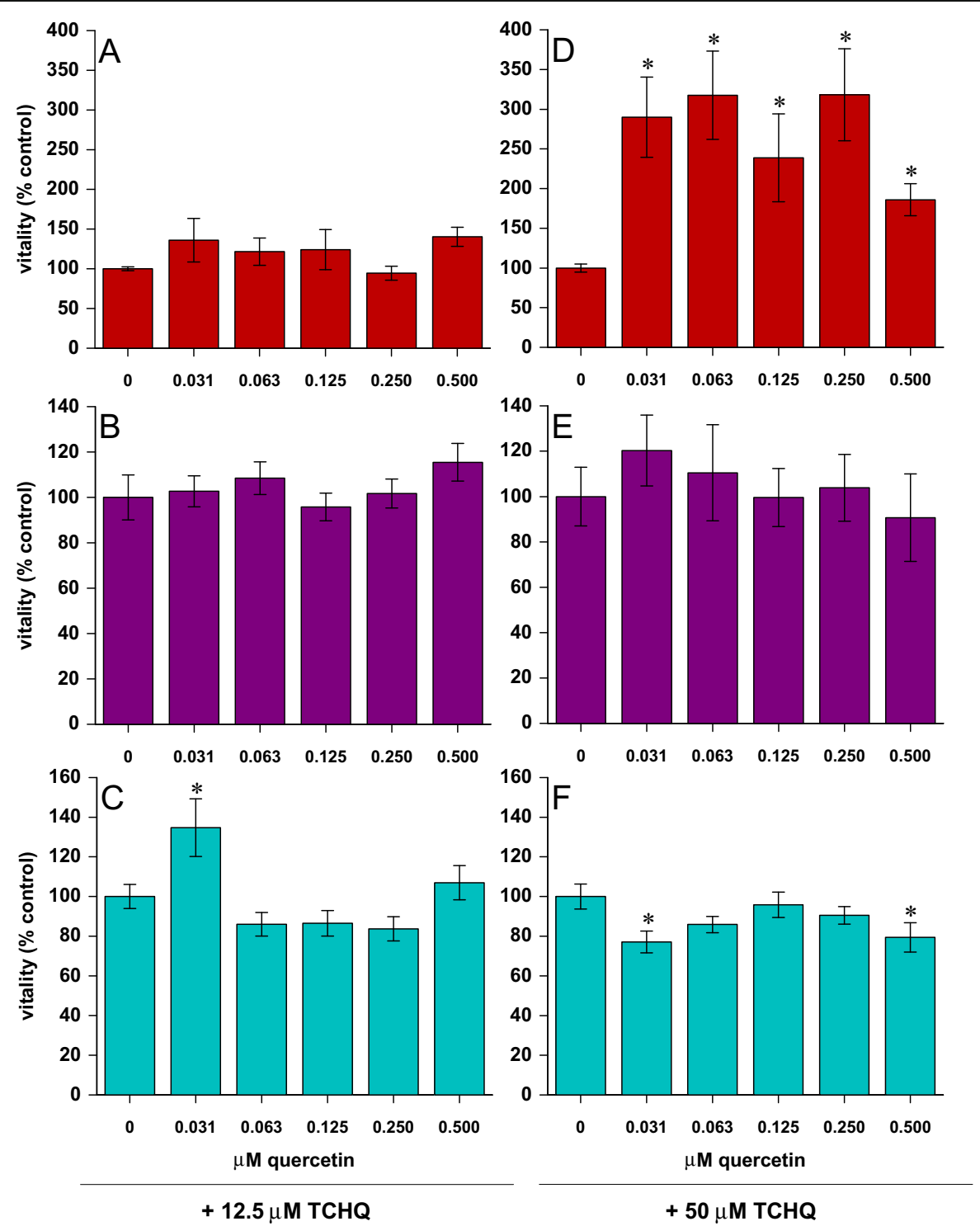

Fig. 12 Effects of preexposure to quercetin on the modulation of NR $\left(12.5 \mu \mathrm{M}\right.$, a-c, and $50 \mu \mathrm{M}$, d-f), mean $\pm \mathrm{SEM},{ }^{*}=P<0.05$

that this is also true for TCHQ in fish cells, although further research should identify the exact target of TCHQ in lysosomal pathways.

The occurrence of cell death after treatment of RTLW1 cells with PCP was further confirmed using the fluorescent dye propidium iodide. Chen et al. (2004) observed necrosis-like mechanisms which lead to cell death by exposure of a mouse connective tissue fibroblast cell line to PCP. In contrast, a recent study on Asian stinging catfish (Heteropneustes fossilis) indicated PCPinduced apoptotic events in several cell types (Ali et al. 2013). The use of the PI method in the present study does not allow distinguishing necrotic cell death from the occurrence of apoptosis although the early onset of increased PI fluorescence favors the former assumption. Nevertheless, further research should provide more evidence for this assumption.

The effects of PCP on ROS production in RTL-W1 cells were less pronounced compared to the exposure to TCHQ which has already been observed in HepG2 cells (Schroeder et al. 2012). The observed cytotoxicity of PCP in RTL-W1 cells is probably due to production of ROS which was increased at a concentration of $12.5 \mu \mathrm{M}$ PCP. Furthermore, the observed decrease of ROS 
production at $50 \mu \mathrm{M}$ PCP may be due to reduced cell viability or detoxification of ROS by cellular systems before excessive ROS production could be detected in our assays. An important part of the enzymatic system for the detoxification of ROS is realized by SOD. In our study, high PCP concentrations increased the SOD activity in RTL-W1 cells. Nevertheless, it can be assumed that the activation of the antioxidative SOD upon exposure to high PCP concentrations was not sufficient to prevent cell damage by ROS. This supports the assumed hazardous potential of PCP in liver cells.

According to Tsai et al. (2001) two pathways of metabolism for PCP are possible. In the present study, it was shown for the first time that fish cells are able to metabolize PCP to TCHQ by one of these mechanisms which is supposed to enhance toxicity and carcinogenicity of PCP in rodents (Lin et al. 1999; Umemura et al. 1999). Thus, TCHQ was also evaluated for possible cytotoxic effects in RTL-W1 cells, which suggested that incubation with TCHQ alone does not lead to more toxic effects in RTL-W1 cells than the exposure to PCP since the $\mathrm{RP}_{\mathrm{TCHQ}}$ values were lower than 1 . However, it is necessary to consider that cells treated with PCP also biotransform this substance to TCHQ within $24 \mathrm{~h}$, and the resulting effects on cell viability are mixed effects of both substances and possible further metabolites. Thus, it is not reasonable to fully estimate the cytotoxicity of TCHQ based on the conducted experiments, and further research is needed to clarify the cytotoxic potency of TCHQ compared to PCP.

Since TCHQ is known to induce oxidative stress in rodents (Lin et al. 1999; Umemura et al. 1999), the effects of TCHQ on ROS production were also evaluated in our studies. Similar to the previous experiments using PCP, the exposure to TCHQ induced ROS production at a low concentration. Higher concentrations of TCHQ reduced the ROS production which is probably due to its effects on cell viability and activation of antioxidative mechanisms in TCHQ-treated cells that are not sufficient to prevent cell death. However, it has been suggested that the effects of PCP and TCHQ on cell viability also depend on the cell type (Wang et al. 1997, 2000), and species-dependent differences in the quantitative metabolism of PCP have been observed in mice and rats (Lin et al. 1999).

In addition, trout is also capable of biotransforming PCP via glucuronidation and to a lesser extent by formation of PCP sulfates (Black et al. 1995; Cravedi et al. 1999). Consequently, further experiments involving fish cell lines from different species are currently employed in our labs to study species-specific cytotoxic effects of TCHQ and PCP and the characteristics of their metabolization in detail.

\section{Effects of ascorbic acid and quercetin on PCP and TCHQ toxicity}

Exposure to ascorbic acid in medium increased intracellular levels of ascorbic acid and increased the tolerance of the RTL-W1 cells to the detrimental effects of PCP and TCHQ to some extent but co-exposure to $50 \mu \mathrm{M}$ PCP revealed that ascorbic acid can also lead to further cellular damage. The beneficial effect of ascorbic acid could be due to its antioxidative capacity and its influence to other antioxidants such as glutathione (Winkler et al. 1994). van Ommen et al. (1986) indicated that the benzoquinone or semiquinone form of TCHQ is inhibited by glutathione through conjugation. However, ascorbic acid is also capable of reducing benzoquinones and semiquinones to hydroquinones so that the transformation of PCP to TCHQ and tetrachloro-1,2-hydroquinone (TCoHQ) is increased. This would lead to increased detrimental effects on cells which may have occurred at higher PCP and TCHQ concentrations.

Quercetin is the member of the group of natural compounds called flavonoids which are known to have antioxidative properties that differ from those of ascorbic acid. Flavonoids are known to scavenge free radicals, inhibit lipid peroxidation, and reduce DNA damage caused by exposure to mutagenic chemicals (Afanasev et al. 1989; Bors et al. 1994; Sestill et al. 1998). Thus, they are subjects of intense research on the basis of their antioxidant, anti-inflammatory, and anticancer activities. In in vitro experiments, quercetin can be effective as an agent reducing the side effects of toxic chemicals without influencing intracellular antioxidants such as glutathione (Kook et al. 2008).

Quercetin alone was not found to be toxic to RTL-W1 cells exposed for $24 \mathrm{~h}$ which is in agreement to other reports on mammalian cell lines that used considerably higher quercetin concentrations (up to $100 \mu \mathrm{M}$ ) but treated the cells for only $30 \mathrm{~min}$ (Sestill et al. 1998). Although quercetin reduced the ROS production alone, it could not prevent toxic effects of PCP and especially at the higher PCP concentration of $50 \mu \mathrm{M}$, quercetin, paradoxically, intensified the detrimental effects on the 
RTL-W1 cells. Similar responses have also been found in menadione-treated HL-60 cells where coculture with quercetin prevented DNA damage, but increased the impairment of membrane integrity and did not increase cell viability as it would be expected from an antioxidant (Bestwick and Milne 2001). This is certainly connected to the fact that flavonoids may also exhibit pro-oxidative characteristics (Miura et al. 1998). The phenomenon was therefore called the "quercetin paradox" (Boots et al. 2007), whereby the prevention of oxidative damage by quercetin leads to the formation of highly reactive quercetin-quinone that depletes glutathione levels and increases membrane damages and intracellular calcium concentrations. In contrast, quercetin was able to reduce the negative effects of TCHQ on RTL-W1 cells probably by acting on redox cycles in the cells and/or prevention of apoptotic events as has been shown for oxidative stress in mammalian systems (Kook et al. 2008).

In conclusion, the present study is the first one that showed the occurrence of TCHQ as a metabolite of PCP in fish cells. Moreover, cytotoxic effects due to oxidative stress by PCP or TCHQ in permanent cell lines of fish have not been demonstrated so far. Thus, our study is an important contribution to the understanding of toxic mechanisms of common environmental chemicals, such as PCP and TCHQ. The antioxidants were able to attenuate the cytotoxic effects of PCP and TCHQ to a certain extent but especially at higher PCP and TCHQ concentrations, ascorbic acid and quercetin add to the detrimental effects on cells. Nevertheless, it remains to be determined whether PCP and its metabolites would reveal the same effects on cell viability and cell function in vivo.

Acknowledgments The authors owe special thanks to the Bundesamt für Umwelt, Wald und Landschaft (BUWAL) in Bern (Switzerland) for financial support of the project "MicroPoll" (project no. StoBoBio/2004.H.15a) which allowed the initial investigations on effects of PCP on RTL W-1 cells. Grateful acknowledgment is also made for the financial support by the "Fonds zur Förderung von Lehre und Forschung" that belongs to the Freiwillige Akademische Gesellschaft (FAG) in Basel (Switzerland) which enabled us to purchase the plate reader Infinite M200 from Tecan Group Ltd. (Switzerland). Furthermore, the authors like to thank Prof. Kristin Schirmer from the Swiss Federal Institute of Aquatic Science and Technology (Eawag, Dübendorf, Switzerland) for providing the liver cell line established from rainbow trout. In addition, we are grateful to Heidi Schiffer for maintaining the cell cultures and additional help in the laboratory work.

\section{References}

Afanasev IB, Dorohzko AL, Brodskii AV, Korstyuk VA, Potapovitch AI. Chelating and free radical scavenging mechanism of inhibitory action of rutin and quercetin in lipid peroxidation. Biochem Pharmacol. 1989;38:1763-8.

Ali MN, Nazam N, Lone MI, Shaikh S, Ahmad W. Evidence of apoptosis in some cell types due to pentachlorophenol (PCP) in Heteropneustes fossilis. Saudi J Biol Sci. 2013;20:45-9.

Babich $\mathrm{H}$, Borenfreund $\mathrm{E}$. In vitro cytotoxicity of organic pollutants to bluegill sunfish (BF-2) cells. Environ Res. 1987;42:229-37.

Bestwick CS, Milne L. Quercetin modifies reactive oxygen levels but exerts only partial protection against oxidative stress within HL-60 cells. Biochim Biophys Acta. 2001;1528:49-59.

Black MC, Björkroth K, Oikari A. Probing the routes, rates, and mechanisms of xenobiotic elimination by rainbow trout (Oncorhynchus mykiss) with a physiological chamber. In: Hughes JS, Biddinger GR, Monas E, editors. Environmental toxicology and risk assessment - Third volume, ASTM STP 1218. Philadelphia: American Society for Testing and Materials; 1995. p. 351-64.

Boots AW, Li H, Schins RPF, Duffin R, Heemskerk JWM, Bast A, et al. The quercetin paradox. Toxicol Appl Pharmacol. 2007;222:89-96.

Borenfreund E, Puerner JA. Toxicity determined in vitro by morphological alterations and neutral red absorption. Toxicol Lett. 1985;24:119-24.

Bors W, Michel C, Saran M. Flavonoids antioxidants: rate constants for reactions with oxygen radicals. Methods Enzymol. 1994;234:420-9.

Caminada D, Escher C, Fent K. Cytotoxicity of pharmaceuticals found in aquatic systems: comparison of PLHC-1 and RTG-2 fish cell lines. Aquat Toxicol. 2006;79:114-23.

Castaño A, Gómez-Lechón MJ. Comparison of basal cytotoxicity data between mammalian and fish cell lines: a literature survey. Toxicol in Vitro. 2005;19:695-705.

Castaño A, Vega MM, Tarazona JV. Acute toxicity of selected metals and phenols on RTG-2 and CHSE-214 fish cell lines. Bull Environ Contam Toxicol. 1995;55:222-9.

Chen J, Jiang J, Zhang F, Yu H, Zhang J. Cytotoxic effects of environmentally relevant chlorophenols on L929 cells and their mechanisms. Cell Biol Toxicol. 2004;20:183-96.

Clemedson C, Barile FA, Ekwall B, Gómez-Lechón MJ, Hall T, Imai K, et al. MEIC evaluation of acute systemic toxicity. III. In vitro results from 16 additional methods used to test the first 30 reference chemicals and a comparative cytotoxicity analysis. Altern Lab Anim. 1998;26(1):93-129.

Cravedi JP, Lafuente A, Baradat M, Hillenweck A, Perdu-Durand E. Biotransformation of pentachlorophenol, aniline and biphenyl in isolated rainbow trout (Oncorhynchus mykiss) hepatocytes: comparison with in vivo metabolism. Xenobiotica. 1999;29:499-509.

Deichman WB, Keplinger ML. Phenols and phenolic compounds. In: Clayton GD, Cayton FE, editors. Patty's industrial hygiene and toxicology. New York: John Wiley and Sons; 1981. p. 2567-627.

Dorsey WC, Tchounwou PB. Pentachlorophenol-induced cytotoxic, mitogenic, and endocrine-disrupting activities in channel catfish, Ictalurus punctatus. Int J Environ Res Public Health. 2004;1:90-9. 
Dorsey WC, Tchounwou PB, Sutton D. Mitogenic and cytotoxic effects of pentachlorophenol to AML 12 mouse hepatocytes. Int J Environ Res Public Health. 2004;1(2):100-5.

Dwyer FJ, Mayer FL, Sappington LC, Buckler DR, Bridges CM, Greer IE, et al. Assessing contaminant sensitivity of endangered and threatened aquatic species: Part I. Acute toxicity of five chemicals. Arch Environ Contam Toxicol. 2005;48:143-54.

Fent K, Hunn J. Cytotoxicity of organic environmental chemicals to fish liver cells (PLHC-1). Mar Environ Res. 1996;42:377-82.

Fernández Freire P, Labrador V, Perez Martin JM, Hazen MJ. Cytotoxic effects in mammalian Vero cells exposed to pentachlorophenol. Toxicology. 2005;210:37-44.

Ge J, Pan J, Fei Z, Wu G, Giesy JP. Concentrations of pentachlorophenol (PCP) in fish and shrimp in Jiangsu Province, China. Chemosphere. 2007;69:164-9.

Glickman AH, Statham CN, Wu A, Lech JJ. Studies on the uptake, metabolism, and disposition of pentachlorophenol and pentachloroanisole in rainbow trout. Toxicol Appl Pharmacol. 1977;41:649-58.

Hanson R, Dodoo DK, Essumang DK, Blay J, Yankson K. The effect of some selected pesticides on the growth and reproduction of fresh water Oreochromis niloticus, Chrysicthys nigrodigitatus and Clarias gariepinus. Bull Environ Contam Toxicol. 2007;79:544-7.

Hodson PV, Blunt BR. Temperature-induced changes in pentachlorophenol chronic toxicity to early life stages of rainbow trout. Aquat Toxicol. 1981;1:113-27.

Johnson WW, Finley MT. Handbook of acute toxicity of chemicals to fish and aquatic invertebrates. Washington, DC: US Department of Interior, Fish and Wildlife Service; 1980. p. 98.

Kook D, Wolf AH, Yu AL, Neubauer AS, Priglinger SG, Kampik A, et al. The protective effect of quercetin against oxidative stress in the human RPE in vitro. Investig Ophthalmol Vis Sci. 2008;49(4):1712-20.

Koss G, Koransky W. Pentachlorophenol in different species of vertebrates after administration of hexachlorobenzene and pentachlorobenzene. In: Rao KR, editor. Pentachlorophenol: chemistry, pharmacology, and environmental toxicology. New York: Plenum Press; 1978. p. 131-7.

Kulikov SM, Holder BJR. Kinetics of acid-assisted hydrolysis of pentachlorophenol in aqueous media. Kinet Catal. 2008;49: 361-5.

Lampi P, Vartiainen T, Tuomisto J. Population exposure to chlorophenols, dibenzo- $p$-dioxins and dibenzofurans after a prolonged ground water pollution by chlorophenols. Chemosphere. 1990;20:625-34.

Lin P, Waidyanatha S, Pollack G, Swenberg J, Rappaport S. Dosespecific production of chlorinated quinone and semiquinone adducts in rodent livers following administration of pentachlorophenol. Toxicol Sci. 1999;47:126-33.

Michel C, Herzog S, de Capitani C, Burkhardt-Holm P, Pietsch C. Natural mineral particles are cytotoxic to rainbow trout gill epithelial cells in vitro. In press in PLOS ONE 2014.

Miura YH, Tomita I, Watanabe T, Hirayama T, Fukui S. Active oxygen generation by flavonoids. Biol Pharm Bull. 1998;21: 93-6.

Mothersill C, Lyng F, Lyons M, Cottell D. Growth and differentiation of epidermal cells from the rainbow trout established as explants and maintained in various media. J Fish Biol. 1995;46(6):1011-25.
Pierce Jr RH, Victor DM. The fate of pentachlorophenol in an aquatic ecosystem. In: Rao KR, editor. Pentachlorophenol: chemistry, pharmacology, and environmental toxicology. New York: London Plenum Press; 1978. p. 41-52.

Pietsch C, Bucheli T, Wettstein F, Burkhardt-Holm P. Frequent biphasic cellular responses of permanent fish cell cultures to deoxynivalenol (DON). Toxicol Appl Pharmacol. 2011;256: 24-34.

Proudfoot AT. Pentachlorophenol poisoning. Toxicol Rev. 2003;22:3-11.

Renner G, Mücke W. Transformation of pentachlorophenol. Toxicol Environ Chem. 1986;11:9-29.

Repetto G, Jos A, Hazen MJ, Molero ML, del Peso A, Salguero M, et al. A test battery for the ecotoxicological evaluation of pentachlorophenol. Toxicol in Vitro. 2001;15:503-9.

Saito H, Sudo M, Shigeoka T, Yamauchi F. In vitro cytotoxicity of chlorophenols to goldfish GF-scale (GFS) cells and quantitative structure-activity relationships. Environ Toxicol Chem. 1991;10:235-41.

Sai-Kato K, Umemura T, Takagi A, Hasegawa R, Tanimura A, Kurokawa Y. Pentachlorophenol-induced oxidative DNA damage in mouse liver and protective effect of antioxidants. Food and Chemical Toxicology. 1995;33:877-882.

Schreer A, Tinson C, Sherry JP, Schirmer K. Application of Alamar blue/5-carboxyfluorescein diacetate acetoxymethyl ester as a noninvasive cell viability assay in primary hepatocytes from rainbow trout. Anal Biochem. 2005;344:76-85.

Schroeder IE, van Tonder JJ, Steenkamp V. Comparative toxicity of pentachlorophenol with its metabolites tetrachloro-1,2hydroquinone and tetrachloro-1,4-benzoquinone in HepG2 cells. Open Toxicol J. 2012;5:11-20.

Schummer C, Sadiki M, Mirabel P, Millet M. Analysis of tbutyldimethylsilyl derivatives of chlorophenols in the atmosphere of urban and rural areas in east of France. Chromatographia. 2006;63:189-95.

Segner H, Lenz D. Cytotoxicity assays with the rainbow trout R1 cell line. Toxicol in Vitro. 1993;7:537-40.

Sestill P, Guidarelli A, Dacha M, Cantoni O. Quercetin prevents DNA single strand breakage and cytotoxicity caused by tertbutylhydroperoxide: free radical scavenging versus iron chelating mechanism. Free Radic Biol Med. 1998;25(2): 196-200.

Smith R, Ord M. Morphological alterations in the mitochondria of Amoeba proteus induced by uncoupling agents. J Cell Sci. 1979;37:217-29.

Song ZH. Effects of pentachlorophenol on Galba pervia, Tubifex sinicus and Chironomus plumousus larvae. Bull Environ Contam Toxicol. 2007;79:278-82.

Spehar RL, Nelson HP, Swanson MJ, Renoos JW. Pentachlorophenol toxicity to amphipods and fathead minnows at different test $\mathrm{pH}$ values. Environ Toxicol Chem. 1985;4:389-97.

Tsai CH, Lin PH, Waidyanatha S, Rappaport SM. Characterization of metabolic activation of pentachlorophenol to quinones and semiquinones in rodent liver. Chem Biol Interact. 2001;134: 55-71.

Uhl S, Schmid P, Schlatter C. Pharmacokinetics of pentachlorophenol in man. Arch Toxicol. 1986;58:182-6.

Umemura T, Kai S, Hasegawa R, Sai K, Kurokawa Y, Williams GM. Pentachlorophenol (PCP) produces liver oxidative stress and 
promotes but does not initiate hepatocarcinogenesis in $\mathrm{B} 6 \mathrm{C} 3 \mathrm{~F} 1$ mice. Carcinogenesis. 1999;20:1115-20.

US EPA. Environmental Protection Agency. Basic information about pentachlorophenol in drinking water. US Environmental Protection Agency Website. Available at http://water.epa.gov/ drink/contaminants/basicinformation/pentachlorophenol.cfm. Accessed at Nov 20, 2013.

van Ommen B, van Bladeren PJ. Possible reactive intermediates in the oxidative biotransformation of hexachlorobenzene. Drug Metabol Drug Interact. 1989;7:213-43.

van Ommen B, van Bladeren PJ, Temmink JH, Muller F. Formation of pentachlorophenol as the major product of microsomal oxidation of hexachlorobenzene. Biochem Biophys Res Commun. 1985;126:25-32.

van Ommen B, Adang A, Müller F, van Bladeren PJ. The microsomal metabolism of pentachlorophenol and its covalent binding to protein and DNA. Chem Biol Interact. 1986;60:1-11.

Vislisel JM, Schafer FQ, Buettner GR. A simple and sensitive assay for ascorbate using a plate reader. Anal Biochem. 2007;365(1):31-9.

Wang YJ, Ho YS, Chu SW, Lien HJ, Liu TH, Lin JK. Induction of glutathione depletion, p53 protein accumulation and cellular transformation by tetrachlorohydroquinone, a toxic metabolite of pentachlorophenol. Chem Biol Interact. 1997;105:1-16.

Wang YJ, Ho YS, Jeng JH, Su HJ, Lee CC. Different cell death mechanisms and gene expression in human cells induced by pentachlorophenol and its major metabolite, tetrachlorohydroquinone. Chem Biol Interact. 2000;128:173-88.

Weinbach EC. The effect of pentachlorophenol on oxidative phosphorylation. J Biol Chem. 1954;210:300-15.

WHO. Pentachlorophenol in drinking-water. Background document for preparation of WHO Guidelines for drinking-water quality. Geneva: World Health Organization; 2003. WHO/ SDE/WSH/03.04/62).

WHO. Pentachlorophenol. In: Environmental health criteria. Geneva: World Health Organization; 1987: pp. 2-4.

Winkler BS, Orselli SM, Rex TS. The redox couple between glutathione and ascorbic acid: a chemical and physiological perspective. Free Radic Biol Med. 1994;17(4):333-49.

Yi H, Ao XL, Ho YS. Use of citation per publication as an indicator to evaluate pentachlorophenol research. Scientometrics. 2008;75:67-80.

Zheng M, Zhu L. Toxicity effects of pentachlorophenol on Brachydanio rerio. Yingyong Shengtai Xuebao. 2005;16: 1967-71. 